\title{
Optimization of cultivation medium and cyclic fed-batch fermentation strategy for enhanced polyhydroxyalkanoate production by Bacillus thuringiensis using a glucose-rich hydrolyzate
}

\author{
Sarisha Singh ${ }^{1 *}$, Bruce Sithole ${ }^{2,3}$, Prabashni Lekha ${ }^{2}$, Kugenthiren Permaul $^{4}$ and Roshini Govinden ${ }^{1}$
}

\begin{abstract}
The accumulation of petrochemical plastic waste is detrimental to the environment. Polyhydroxyalkanoates (PHAs) are bacterial-derived polymers utilized for the production of bioplastics. PHA-plastics exhibit mechanical and thermal properties similar to conventional plastics. However, high production cost and obtaining high PHA yield and productivity impedes the widespread use of bioplastics. This study demonstrates the concept of cyclic fed-batch fermentation (CFBF) for enhanced PHA productivity by Bacillus thuringiensis using a glucose-rich hydrolyzate as the sole carbon source. The statistically optimized fermentation conditions used to obtain high cell density biomass $\left(\mathrm{OD}_{600}\right.$ of 2.4175) were: $8.77 \mathrm{~g} \mathrm{~L}^{-1}$ yeast extract; $66.63 \%$ hydrolyzate $(\mathrm{v} / \mathrm{v})$; a fermentation $\mathrm{pH}$ of 7.18 ; and an incubation time of $27.22 \mathrm{~h}$. The CFBF comprised three cycles of $29 \mathrm{~h}, 52 \mathrm{~h}$, and $65 \mathrm{~h}$, respectively. After the third cyclic event, cell biomass of $20.99 \mathrm{~g} \mathrm{~L}^{-1}$, PHA concentration of $14.28 \mathrm{~g} \mathrm{~L}^{-1}$, PHA yield of $68.03 \%$, and PHA productivity of $0.219 \mathrm{~g} \mathrm{~L}^{-1} \mathrm{~h}^{-1}$ was achieved. This cyclic strategy yielded an almost threefold increase in biomass concentration and a fourfold increase in PHA concentration compared with batch fermentation. FTIR spectra of the extracted PHAs display prominent peaks at the wavelengths unique to PHAs. A copolymer was elucidated after the first cyclic event, whereas, after cycles CFBF 2-4, a terpolymer was noted. The PHAs obtained after CFBF cycle 3 have a slightly higher thermal stability compared with commercial PHB. The cyclic events decreased the melting temperature and degree of crystallinity of the PHAs. The approach used in this study demonstrates the possibility of coupling fermentation strategies with hydrolyzate derived from lignocellulosic waste as an alternative feedstock to obtain high cell density biomass and enhanced PHA productivity.
\end{abstract}

Keywords: Polyhydroxyalkanoate, Glucose-rich hydrolyzate, Response surface methodology, Cyclic fed-batch fermentation, PHA productivity, Pulp and paper mill sludge

\section{Introduction}

An estimated 240 million tons of plastics are produced globally every year. Most of these plastic materials are petroleum-based and are resistant to

\footnotetext{
*Correspondence: sarish_s@yahoo.com; 207506565@stu.ukzn.ac.za

1 Discipline of Microbiology, University of KwaZulu-Natal (Westville

Campus), Durban, South Africa

Full list of author information is available at the end of the article
}

degradation resulting in accumulation and pollution of forestry and marine environments (Gholamveisi et al. 2018). With crude oil reserves dwindling, the dependence on exhaustible fossil fuel resources is unsustainable. This can be mitigated by the exploitation of biopolymers, i.e., natural polymers generated by living organisms, consisting of monomeric units that are covalently bonded to form larger molecules. Examples 
include polyhydroxyalkanoates (PHAs) such as polyhydroxybutyrate $(\mathrm{PHB})$ and polyhydroxybutyrate-valerate copolymer (PHBV) that occur as intracellular granules produced by bacteria and are accumulated by the cell to act as carbon and energy storage reserves (Sheu et al. 2000; Sin et al. 2014). PHAs are considered to be carbonneutral and environment-friendly. Research into PHAs has intensified since the discovery that PHA-bioplastics are non-toxic, biodegradable and that their mechanical, physical, and thermal characteristics are similar to fossil fuel-based plastics, such as polypropylene and polyethylene (Muhammadi et al. 2015). Thus, PHAs have the potential to replace fossil fuel-derived plastics. However, the PHA production cost is a significant problem as carbon source alone accounts for $45 \%$ of the total production cost, hindering the market growth of PHA-based plastics (Annamalai et al. 2017). For PHAs to be cost-competitive with petroleum-derived plastics, sustainable, renewable, and cheaper alternative carbon source substrates need to be explored. Furthermore, employing microbial strains capable of high cell density growth and PHA production in waste-derived cultivation media will also be beneficial.

Waste biomass is an attractive alternative source of fermentable sugars for application as inexpensive feedstock for the production of platform chemicals (Moritz and Duff 1996; Peters 2006; Prasetyo et al. 2010; Martin-Sampedro et al. 2011). Glucose-rich hydrolyzate obtained from corrugated cardboard was used as a nutrient source for yeast proliferation (García et al. 2015). Hydrolyzates obtained from enzymolysis of recycled paper sludge was used for the production of lactic acid by bacteria (Marques et al. 2008), primary clarifier sludge from kraft and low-yield sulfite pulping operations (Duff et al. 1994) and recycled paper sludge (Madrid and Díaz 2011; Schroeder et al. 2015) was used in bio-ethanol production.

Moreover, hydrolyzates from wheat bran (Annamalai and Sivakumar 2016), waste office paper (Annamalai et al. 2017), and wheat straw (Ferreira and Schlottbom 2016) were successful as alternative substrates for PHB production. Bacillus species have an innate ability to produce a variety of hydrolytic enzymes enabling them to metabolize complex residues and utilize a diverse array of carbon wastes (Rohini et al. 2006). Thus, there is a growing interest in exploring native Bacillus strains and their potential to use agro-wastes residues and hydrolyzates for PHA production. Bacillus strains such as $B$. thuringiensis B417-5 and B. thuringiensis strain IAM 12077 displayed PHB-producing capability when using hydrolyzates from agro-waste residues (Gowda and Shivakumar 2014; Thammasittirong et al. 2017).

To enhance product yields, high cell density cultivations and high productivity during fermentation should be achieved, particularly for intracellular compounds.
The development of high cell density cultivation strategies fundamentally uses different types of bioreactors and cultivation strategies (Ibrahim and Steinbüchel 2010). One such strategy is cyclic fed-batch fermentation (CFBF) that was first described by Pirt (1974) for penicillin production and has since been applied for enhanced production of antibiotics (Lynch and Bushell 1995), recombinant proteins (Argyropoulos and Lynch 1997), and PHAs (Ibrahim and Steinbüchel 2010; Haas et al. 2017; Gahlawat and Srivastava 2018). The CFBF process entails the partial withdrawal of fermentation medium and subsequent re-filling with an equal volume of fresh fermentation medium. The chemical composition of the fermentation medium must be consistent throughout the "empty-and-fill" process. The CFBF strategy prevents increases in concentrations of toxic by-products and enhances cell growth to achieve high concentrations of final biomass and increased PHA yields (Ibrahim and Steinbüchel 2010; Gahlawat and Srivastava 2018).

This study reports the practicality of employing Bacillus thuringiensis in a CFBF cultivation using glucose-rich hydrolyzate derived from enzymatic saccharification of pulp and paper mill sludge as the sole carbon source. Firstly, a statistical optimization study was conducted to elucidate the optimal fermentation medium to produce high cell density biomass. The initial use of batch fermentation was to assist in determining kinetic parameters. Thereafter, the CFBF cultivation strategy was used to enhance cell density and PHA production by $B$. thuringiensis. A comparison between batch fermentation and CFBF was performed to evaluate PHA yield and productivity. Lastly, PHAs were extracted after each cycle and characterized to determine their composition and thermal stability and compared with commercial PHB and PHBV.

\section{Materials and methods}

Bacterial strain, growth, and storage conditions

B. thuringiensis DF7 (Accession no. KC020161), previously isolated from Eucalyptus dunnii wood chips obtained from a plantation in Durban, South Africa, was used. The bacterium was stored at $4{ }^{\circ} \mathrm{C}$ on nutrient agar for short-term maintenance and, $40 \%$ glycerol stock cultures were stored at $-80^{\circ} \mathrm{C}$ for long-term storage.

\section{Hydrolyzate production}

A glucose-rich hydrolyzate was extracted from dry deashed pulp and paper mill sludge (PPMS) as per the method outlined by Singh et al. (2021). Briefly, PPMS obtained from a prehydrolysis kraft and kraft (PHKK) pulping mill was de-ashed using acidic pretreatment.

A five-factor Box-Behnken design was used to optimize the conditions for the maximum recovery of glucose 
Table 1 Independent variables with their respective coded values and levels used in the Box-Behnken design

\begin{tabular}{lllll}
\hline Coded value & Independent variable & \multicolumn{3}{l}{ Level } \\
\cline { 3 - 5 } & & Low & Middle & Upper \\
& & $-\mathbf{1}$ & $\mathbf{0}$ & $\mathbf{+ 1}$ \\
\hline$X_{1}$ & Yeast extract $\left(\mathrm{g} \mathrm{L}^{-1}\right)$ & 6 & 8 & 10 \\
$\mathrm{X}_{2}$ & Hydrolyzate $(\% \mathrm{v} / \mathrm{v})$ & 50 & 75 & 100 \\
$\mathrm{X}_{3}$ & Time $(\mathrm{h})$ & 18 & 24 & 30 \\
$\mathrm{X}_{4}$ & $\mathrm{pH}$ & 7.0 & 7.2 & 7.4 \\
\hline
\end{tabular}

$\left(\mathrm{g} \mathrm{L}^{-1}\right)$ from dry de-ashed PPMS fiber. After model validation, the observed yield of glucose was $20.56 \mathrm{~g} \mathrm{~L}^{-1}$. The hydrolyzate contained trace amounts of xylose (2.62\%) and mannose $(0.89 \%)$ as well as low concentrations of toxins such as hemicellulose-derived acetic acid (0.25\%), sugar-derived furans (1.06\%), and lignin-derived phenols (0.58\%).

\section{Cultivation medium for high cell density production}

Biomass production was conducted using shake-flask cultivation in $25 \mathrm{~mL}$ stoppered conical flasks. The cultivation medium included: $1.5 \mathrm{~g} \mathrm{~L}^{-1}\left(\mathrm{NH}_{4}\right)_{2} \mathrm{SO}_{4}, 0.2 \mathrm{~g} \mathrm{~L}^{-1}$ $\mathrm{MgSO}_{4} \cdot 7 \mathrm{H}_{2} \mathrm{O}, 2.5 \mathrm{~g} \mathrm{~L}^{-1} \mathrm{NaCl}, 1.5 \mathrm{~g} \mathrm{~L}^{-1} \mathrm{KH}_{2} \mathrm{PO}_{4}$, and $1.5 \mathrm{~mL} \mathrm{~L}^{-1}$ trace element solution. The concentration of yeast extract and glucose-rich hydrolyzate and the medium $\mathrm{pH}$ were varied as per the model design (Table 2). All flasks were incubated at $37{ }^{\circ} \mathrm{C}$ in an orbital shaker (New Brunswick Innova 44, Eppendorf) at $200 \mathrm{rpm}$ for the relevant times (Table 2). After incubation, a $1 \mathrm{~mL}$ aliquot was aspirated, and cell density was recorded as the optical density at $600 \mathrm{~nm}\left(\mathrm{OD}_{600}\right)$ using a spectrophotometer (Varian Cary $60 \mathrm{UV} / \mathrm{Vis}$

Table 2 The actual, predicted, and residual responses for each experimental run using the Box-Behnken design for high cell density production

\begin{tabular}{|c|c|c|c|c|c|c|c|}
\hline \multirow[t]{2}{*}{ Experimental run } & \multicolumn{4}{|l|}{ Variables } & \multicolumn{3}{|c|}{ Cell density $\left(\mathrm{OD}_{600}\right)$} \\
\hline & $\begin{array}{l}\text { Yeast extract (g } \\
\mathrm{L}^{-1} \text { ) }\end{array}$ & Hydrolyzate (\% v/v) & Time (h) & $\mathrm{pH}$ & Actual & Predicted & Residual \\
\hline 1 & 6 & 50 & 24 & 7.2 & 2.0359 & 2.0517 & -0.0158 \\
\hline 2 & 10 & 50 & 24 & 7.2 & 2.1195 & 2.0293 & 0.0902 \\
\hline 3 & 6 & 100 & 24 & 7.2 & 1.3056 & 1.4088 & -0.1032 \\
\hline 4 & 10 & 100 & 24 & 7.2 & 1.7119 & 1.7091 & 0.0028 \\
\hline 5 & 8 & 75 & 18 & 7.0 & 1.6736 & 1.5987 & 0.0749 \\
\hline 6 & 8 & 75 & 30 & 7.0 & 1.9265 & 1.9670 & -0.0405 \\
\hline 7 & 8 & 75 & 18 & 7.4 & 1.6336 & 1.6061 & 0.0275 \\
\hline 8 & 8 & 75 & 30 & 7.4 & 1.8854 & 1.9733 & -0.0879 \\
\hline 9 & 8 & 75 & 24 & 7.2 & 2.2129 & 2.1609 & 0.0519 \\
\hline 10 & 6 & 75 & 24 & 7.0 & 1.8923 & 1.8377 & 0.0546 \\
\hline 11 & 10 & 75 & 24 & 7.0 & 1.8094 & 1.8706 & -0.0613 \\
\hline 12 & 6 & 75 & 24 & 7.4 & 1.8057 & 1.7384 & 0.0672 \\
\hline 13 & 10 & 75 & 24 & 7.4 & 1.9349 & 1.9835 & -0.0486 \\
\hline 14 & 8 & 50 & 18 & 7.2 & 1.7275 & 1.7876 & -0.0601 \\
\hline 15 & 8 & 100 & 18 & 7.2 & 1.2236 & 1.1973 & 0.0262 \\
\hline 16 & 8 & 50 & 30 & 7.2 & 2.0264 & 2.0466 & -0.0203 \\
\hline 17 & 8 & 100 & 30 & 7.2 & 1.7399 & 1.6739 & 0.0660 \\
\hline 18 & 8 & 75 & 24 & 7.2 & 2.1112 & 2.1349 & -0.0238 \\
\hline 19 & 6 & 75 & 18 & 7.2 & 1.7387 & 1.7779 & -0.0392 \\
\hline 20 & 10 & 75 & 18 & 7.2 & 1.8382 & 1.8676 & -0.0294 \\
\hline 21 & 6 & 75 & 30 & 7.2 & 2.1328 & 2.09634 & 0.0364 \\
\hline 22 & 10 & 75 & 30 & 7.2 & 2.3309 & 2.2847 & 0.0463 \\
\hline 23 & 8 & 50 & 24 & 7.0 & 2.1408 & 2.1552 & -0.0144 \\
\hline 24 & 8 & 100 & 24 & 7.0 & 1.2805 & 1.2938 & -0.0133 \\
\hline 25 & 8 & 50 & 24 & 7.4 & 1.8025 & 1.7821 & 0.0203 \\
\hline 26 & 8 & 100 & 24 & 7.4 & 1.7019 & 1.6804 & 0.0214 \\
\hline 27 & 8 & 75 & 24 & 7.2 & 2.2071 & 2.2352 & -0.0281 \\
\hline
\end{tabular}


spectrophotometer; Agilent Technologies) against a blank of the $1 \mathrm{~mL}$ respective uninoculated cultivation medium.

\section{Statistical optimization of fermentation medium}

For this study, a Box-Behnken design (BBD) was applied to elucidate the optimal cultivation medium to obtain high cell density biomass. The design determined the concentration of yeast extract, the concentration of glucose-rich hydrolyzate, incubation time, and $\mathrm{pH}$ (independent variables) to obtain maximum cell density and any interaction(s) between different combination(s) of variables. The four factors studied in the design were designated as $\mathrm{X}_{1}, \mathrm{X}_{2}, \mathrm{X}_{3}$, and $\mathrm{X}_{4}$, respectively, and prescribed at three different levels (Table 1). The design generated a total of 27 experimental runs.

The results from the experimental runs were analyzed and interpreted using Design-Expert software V 12 (StatEase). Based on the cell density response and interaction of the variables, a multiple regression analysis of independent variables was used, and a second-order polynomial was fitted to the response data obtained from the design.

The second-order polynomial equation generated was as follows:

$$
Y=\beta_{0}+\beta_{i} X_{i}+\beta_{i j} X_{i} X_{j}+\beta_{i i} X_{i}^{2},
$$

where $Y$ is the predicted response, $\beta_{0}$ is the model constant, $\beta_{i}$ is the linear coefficient, $\beta_{i i}$ is the quadratic coefficient, $\beta_{i j}$ is the interaction coefficient, and $X_{i}$ is the independent variable. The statistically not significant parameters $(p>0.05)$ and their interactions were omitted from the equation.

\section{Data analysis}

The ANOVA test was applied to determine the statistical significance $(p<0.05)$ of the BBD. Adequacy of models was checked by analysis of $R^{2}$ and the $R^{2}$ adjusted. The capability and statistical significance of the model equation and the model terms were evaluated by the $F$-test (Cao et al. 2008). The $F$-value is also checked to find out the significance of all the fitted equations at a $5 \%$ level of significance (Hanrahan et al. 2007; Smitha and Pradeep 2017; Czyrski and Sznura 2019). To visualize the relationship between response and experimental levels of a statistically significant factor(s) and to determine the optimum conditions, the fitted equations were expressed as 3-dimensional (3D) surface plots. Surface plots were determined by holding the other independent parameters at a constant middle range value.

\section{Model validation}

To validate the predicted value, experimental trials were conducted to determine the observed value using the optimum values for variables given by the second-order polynomial equation, critical values, and response surface plots. After model validation, the statistically optimized medium was used for seed and inoculum development, as well as the cultivation medium for the batch and CFBF.

\section{Batch fermentation and CFBF}

Based on the results obtained from statistical optimization of the cultivation medium, the medium was prepared and used in downstream processes. For the batch and CFBF, the pre-inoculum was developed in $10 \%(\mathrm{v} / \mathrm{v})$ suspensions in stoppered conical flasks and incubated at $37{ }^{\circ} \mathrm{C}$ in an orbital shaker (New Brunswick Innova 44, Eppendorf) at $200 \mathrm{rpm}$; for the optimal incubation time to produce high cell density biomass as determined from the BBD. The batch and CFBF cultivations of $B$. thuringiensis were conducted in a $2 \mathrm{~L}$ stoppered conical flask containing $500 \mathrm{~mL}$ optimized cultivation medium. For the fermentation, flasks were incubated at $37{ }^{\circ} \mathrm{C}$ in an orbital shaker (New Brunswick Innova 44, Eppendorf) and maintained at $200 \mathrm{rpm}$. CFBF was initiated as described for batch fermentation; however, when glucose concentration had depleted to a limiting concentration $\left(\sim 8 \mathrm{~g} \mathrm{~L}^{-1}\right)$, the batch cultivation was converted to nutrient feed cycle mode wherein $20 \%(\mathrm{v} / \mathrm{v})$ of the fermentation medium was removed from the flask and replenished with an equal volume of fresh medium (having the same composition as the starting medium). Four cycles of repeated-batch cultivation were executed in this manner. At the end of the batch cultivation and after each cycle of the CFBF, the residual carbohydrate content $\left(\mathrm{g} \mathrm{L}^{-1}\right)$, cell biomass (cell dry weight) (CDW; $\mathrm{g} \mathrm{L}^{-1}$ ), and PHA produced $\left(\mathrm{g} \mathrm{L}^{-1}\right)$ were determined. The PHAs extracted at the end of each cycle were confirmed by polymer characterization analyses. The batch and CFBF were conducted in duplicate on two separate occasions.

\section{PHA extraction}

PHAs were recovered using solvent extraction followed by non-solvent precipitation, as per the methodology of Munir et al. (2015). The hypochlorite-chloroform dispersion method is a simple and rapid method routinely used to recover high yields of PHA from cell biomass with high purity (Kunasundari and Sudesh 2011; Aramvash et al. 2018). The bacterial biomass was harvested by centrifugation at $5752 \times g$ for $20 \mathrm{~min}$ to form a pellet that was washed twice with distilled water and lyophilized. The cell dry weight of the lyophilized cells was determined gravimetrically. Thereafter, the lyophilized cells were transferred into 
a conical flask to which $100 \mathrm{~mL}$ of $5 \%$ sodium hypochlorite and $100 \mathrm{~mL}$ of chloroform were added. The mixture was agitated in a rotary shaker (New Brunswick Innova 44, Eppendorf) at $300 \mathrm{rpm}$ at $37^{\circ} \mathrm{C}$ for $3 \mathrm{~h}$. The suspension was transferred into a separating funnel and left to stand for $30 \mathrm{~min}$ to allow phases to separate viz., an upper phase containing hypochlorite solution, a middle phase containing non-PHA material (cell debris and undisrupted cells), and the bottom phase consisting of PHA solubilized in chloroform. The bottom phase was decanted into a beaker, and nine parts of methanol was added to precipitate the PHAs. Finally, the PHA-precipitate was dried by evaporation at $30{ }^{\circ} \mathrm{C}$, resulting in white flakes or powder. The dry weight of the extracted PHAs was determined gravimetrically.

The percentage yield of PHAs was determined using the following equation:

$$
\text { Yield }(\%)=\frac{\operatorname{PHAs}(\mathrm{g})}{\operatorname{CDW}(\mathrm{g})} \times 100
$$

The volumetric bacterial biomass productivity was determined using the following equation:

$$
\text { Productivity }\left(\mathrm{g} \mathrm{L}^{-1} \mathrm{~h}^{-1}\right)=\frac{\mathrm{CDW}\left(\mathrm{g} \mathrm{L}^{-1}\right)}{\operatorname{Time}(\mathrm{h})}
$$

The volumetric PHA productivity was determined using the following equation:

$$
\operatorname{Productivity}\left(\mathrm{g} \mathrm{L}^{-1} \mathrm{~h}^{-1}\right)=\frac{\operatorname{PHAs}\left(\mathrm{gL}^{-1}\right)}{\operatorname{Time}(\mathrm{h})}
$$

\section{High-performance liquid chromatography (HPLC)}

In order to quantitatively determine glucose in the fermentation medium, samples were prepared using standard Technical Association of the Pulp and Paper Industry (TAPPI) method T $249 \mathrm{~cm}-09$ and analyzed using HPLC.

\section{Fourier transform infrared spectroscopy (FTIR)}

The chemical structure of the extracted PHAs and commercial PHB and PHBV (Sigma Aldrich) were analyzed by FTIR. The presence of functional groups representative of PHAs were observed in infrared spectra of the powdered samples recorded in the wavenumber range from 600 to $4000 \mathrm{~cm}^{-1}$ using a Perkin Elmer spectrophotometer (Jasco FTIR-6100).

\section{Polymer composition}

Thermally assisted hydrolysis and methylation-gas chromatography (THM-GC) using pyrolysis/GC-MS (Py/ GC-MS) in the presence of strong organic alkali, tetramethylammonium hydroxide (TMAH), was employed to qualitatively and quantitatively elucidate the polymer composition of the extracted PHAs and commercial PHB and PHBV (Sigma Aldrich) (Torri et al. 2014). The main peaks observed were identified by comparing the mass spectra with the NIST library database. The compounds were identified based on retention time and mass spectra, with only similarities $\geq 85 \%$ considered genuine fits. The polymer composition (mol\%) of each PHA was calculated using the methodology of Martínez-Sanz et al. (2014):

$$
H_{\mathrm{a}, \mathrm{b}, \mathrm{c}}(\%)=\frac{\operatorname{areaH}_{\mathrm{a}, \mathrm{b}, \mathrm{c}}}{\operatorname{areaH}_{\mathrm{a}}+\operatorname{areaH}_{\mathrm{b}}+\operatorname{areaH}_{\mathrm{c}}} \times 100
$$

where $\mathrm{a}, \mathrm{b}$, and $\mathrm{c}$ represent the monomers polyhydroxybutyrate $(\mathrm{HB})$, polyhydroxyvalerate $(\mathrm{HV})$, or polyhydroxyhexanoate $(\mathrm{HHx})$, respectively.

\section{Thermogravimetric analysis (TGA) and differential scanning calorimetry (DSC)}

Thermogravimetric analysis was used to analyze the thermal stability of the extracted PHAs and commercial PHB and PHBV (Sigma). TGA was conducted using a TGA Q5000 (TA Instruments) with a temperature range from 30 to $600{ }^{\circ} \mathrm{C}$ and a heating rate of $10^{\circ} \mathrm{C} \mathrm{min}^{-1}$ in a nitrogen atmosphere $\left(\mathrm{N}_{2}\right.$ flow rate $\left.=40 \mathrm{~mL} \mathrm{~min}{ }^{-1}\right)$. The initial degradation temperature $\left(\mathrm{T}_{5 \%}\right)$ and maximum decomposition temperature $\left(\mathrm{T}_{\max }\right)$ are the temperatures at which $5 \%$ and $95 \%$ weight loss occurred and were determined by analyzing the TGA and derivative thermogravimetric (DTG) graphs, respectively (Pradhan et al. 2018).

A differential scanning calorimeter (DSC Q2000, TA Instruments) was used to perform DSC analysis, where $10 \mathrm{mg}$ of sample was loaded in an aluminum pan and heated from -10 to $200{ }^{\circ} \mathrm{C}$ at a heating rate of $10{ }^{\circ} \mathrm{C} \mathrm{min}{ }^{-1}$. A heating and cooling rate of $10{ }^{\circ} \mathrm{C} \mathrm{min}{ }^{-1}$ was used as well as a nitrogen environment with a gas flow of $20 \mathrm{~mL} \mathrm{~min}{ }^{-1}$. The glass transition temperature $\left(T_{\mathrm{g}}\right)$ was identified as the point of inflection in the thermogram between onset and offset temperatures. The melting temperature $\left(T_{\mathrm{m}}\right)$ and melting enthalpy $\left(\Delta H_{\mathrm{m}}\right)$ were determined from the peak temperature and area under the peak of an endothermic event in the second heating cycle, respectively. The crystallization temperature $\left(T_{\mathrm{c}}\right)$ and crystallization enthalpy $\left(\Delta H_{\mathrm{c}}\right)$ were determined from the peak temperature and area under the peak of an exothermic event in the cooling cycle, respectively. The degree of crystallinity $\left(X_{\mathrm{c}}\right)$ was calculated by dividing $\Delta H_{\mathrm{m}}$ by $146 \mathrm{~J} \mathrm{~g}^{-1}$ (melting enthalpy of $100 \%$ crystalline PHB) (Pradhan et al. 2018). TGA and DSC analysis were conducted in duplicate for each PHA.

\section{Statistical analysis}

The effects of batch fermentation and each cycle of the CFBF on the yield of CDW and PHA as well as on polymer composition were determined using one-way 
ANOVA and SPSS (V 27.0). Where necessary, a Bonferroni post hoc analysis was conducted, and a $p<0.05$ was considered as statistically significant.

\section{Results and discussion}

Statistical optimization of biomass fermentation medium A BBD with four factors, with replicated center points, was used for statistical optimization of the fermentation medium for the production of high cell density biomass. The parameters tested were; yeast extract $(A)$, hydrolyzate concentration $(B)$, incubation time $(C)$, and $\mathrm{pH}$ $(D)$ of the fermentation medium (Table 2). This model was used to determine the effects of individual or combined interactions of the four independent variables on the yield of biomass. The experimental conditions, batch runs, as well as the corresponding actual, predicted, and residual responses for biomass yield are represented in Table 2 and Fig. 1. An increase in cell density from $\mathrm{OD}_{600}$ of 1.8094 to 1.8923 was noted when the concentration of yeast extract decreased from 10 to $6 \mathrm{~g} \mathrm{~L}^{-1}$ (runs 10 and 11). An increase in the concentration of hydrolyzate from 50 to $100 \%$ negatively affected cell proliferation (runs 14 and 15), whereby cell density decreased from $\mathrm{OD}_{600}$ of 1.7275 to 1.2236 . The effect of $\mathrm{pH}$ is observed in runs 23 and 25, where a pH of 7 (closer to neutral) favored high cell density production with an $\mathrm{OD}_{600}$ of 2.1408 noted compared with $\mathrm{pH} 7.4$, where an $\mathrm{OD}_{600}$ of 1.8025 was observed. A longer fermentation time also favored high cell density production (runs 5 and 6), where an increase in cultivation time from 18 to $30 \mathrm{~h}$ increased cell density from $\mathrm{OD}_{600} 1.6736$ to 1.9265 (Table 2). The highest $\mathrm{OD}_{600}$ of 2.3309 was noted for run 22 using the conditions: $10 \mathrm{~g} \mathrm{~L}^{-1}$ yeast extract; $75 \%$ hydrolyzate; incubation for $30 \mathrm{~h}$; and a fermentation medium at $\mathrm{pH} 7.2$. It was

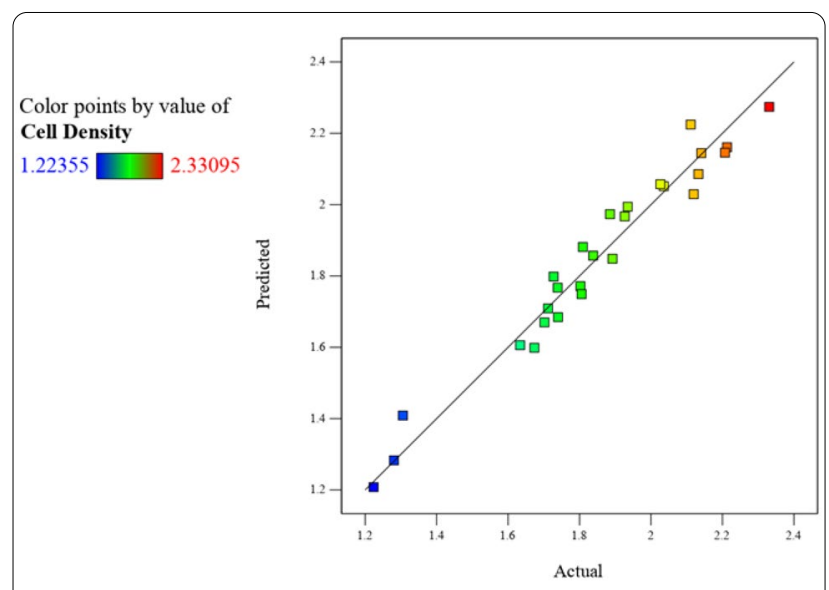

Fig. 1 Graphical representation of the minimal difference between the actual (straight line) and predicted responses (squares) for the Box-Behnken design to obtain high cell density observed that the predicted and the actual experimental responses of biomass are comparable, with minimal difference noted between the data (Fig. 1). The minimal deviation from the straight line indicates less variation from the predicted value and is a satisfactory correlation between experimental data and predictive data, thus proving a high prognostic ability of the BBD (Tesfaye et al. 2018a).

The responses of predicted and experimental values were computed by means of ANOVA to determine the ability of the polynomial expression to predict the responses statistically. The ANOVA for the quadratic model of the response for cell density yield is presented in Table 3. The processed data from the experimental design enabled the calculation of the coefficients of the regression equation. The second-order polynomial equation is as follows:

$$
\begin{aligned}
\text { Response : biomass }\left(\mathrm{OD}_{600}\right) \\
=+2.18+0.0695 A+0.2408 B+0.0034 C \\
\quad+0.1839 D+0.0807 A B+0.0530 A C+0.0247 A D \\
\quad+0.1899 B C+0.0544 B D-0.0003 C D-0.0656 A^{2} \\
\quad-0.2956 B^{2}-0.2117 C^{2}-0.1630 D^{2}
\end{aligned}
$$

where $A, B, D, B C, B^{2}, C^{2}$, and $D^{2}$ were the statistically significant model terms indicating confidence in the results for the parameters yeast extract concentration $(A)$, hydrolyzate concentration $(B)$, incubation time $(C)$, and $\mathrm{pH}(D)$.

The mathematical model equation for the production of biomass is within the limits of the conditions tested. Analysis of the regression equation infers that maximum cell density production of 2.3309 at $\mathrm{OD}_{600}$ is within the selected factor ranges and is influenced by all of the independent variables either in linear or quadratic terms. When considered in linear terms, the concentration of hydrolyzate $(B)$ and incubation time $(D)$ showed the greatest influence on biomass production. This suggests that biomass production should be relatively insensitive to linear variation of the other parameters. When considered with respect to quadratic terms, the concentration of hydrolyzate, reaction time, and $\mathrm{pH}$ had positive significance on biomass production (Table 3). The only significant interactive effect of variables was between hydrolyzate concentration and time $(\mathrm{BC})(p<0.05)$, indicating that this strong interaction has a positive significance on yielding high cell density biomass (Table 3 ). The negative values of coefficients of the regression equation confirm that an increase in the value of any of the factors will decrease the biomass yield. The model $F$-value of 16.13 and $p<0.01$ implies that the model is significant, and there is a $0.01 \%$ chance that an $F$-value this large can be due to noise. The ANOVA indicated that this regression 
Table 3 ANOVA for response surface quadratic model for biomass production by $B$. thuringiensis

\begin{tabular}{|c|c|c|c|c|c|}
\hline Source & Sum of squares & Degrees of freedom & Mean square & $F$-value & $p$-value \\
\hline Model & 1.94 & 14 & 0.1384 & 16.13 & $<0.0001^{* *}$ \\
\hline A-yeast extract & 0.0580 & 1 & 0.0580 & 6.75 & $0.0266^{*}$ \\
\hline B-hydrolyzate & 0.6956 & 1 & 0.6956 & 81.04 & $<0.0001^{* *}$ \\
\hline $\mathrm{C}-\mathrm{pH}$ & 0.0001 & 1 & 0.0001 & 0.0162 & 0.9012 \\
\hline D-time & 0.4058 & 1 & 0.4058 & 47.27 & $<0.0001^{* *}$ \\
\hline$A B$ & 0.0260 & 1 & 0.0260 & 3.03 & 0.1122 \\
\hline$A C$ & 0.0113 & 1 & 0.0113 & 1.31 & 0.2789 \\
\hline$A D$ & 0.0024 & 1 & 0.0024 & 0.2837 & 0.6059 \\
\hline$B C$ & 0.1443 & 1 & 0.1443 & 16.81 & $0.0021^{*}$ \\
\hline$B D$ & 0.0118 & 1 & 0.0118 & 1.38 & 0.2677 \\
\hline$C D$ & $3.306 \times 10^{-7}$ & 1 & $3.306 \times 10^{-7}$ & 0.0000 & 0.9952 \\
\hline$A^{2}$ & 0.0230 & 1 & 0.0230 & 2.68 & 0.1329 \\
\hline$B^{2}$ & 0.4661 & 1 & 0.4661 & 54.30 & $<0.0001^{* *}$ \\
\hline$C^{2}$ & 0.2391 & 1 & 0.2391 & 27.85 & $0.0004^{* *}$ \\
\hline$D^{2}$ & 0.1417 & 1 & 0.1417 & 16.50 & $0.0023^{*}$ \\
\hline Residual & 0.0858 & 10 & 0.0086 & & \\
\hline$R^{2}$ & 0.9576 & & & & \\
\hline Adjusted $R^{2}$ & 0.8982 & & & & \\
\hline
\end{tabular}

*Significant $(p<0.05) 5 \%$ level of significance

**Highly significant $(p<0.01) 1 \%$ level of significance

model was highly significant $(p<0.01)$. The value of $p>F$ $<0.001$ implies that the model terms are significant and that there is less than a $1 \%$ chance that the observed values were due to chance. $R^{2}$ or coefficient of determination is the proportion of variation in the response attributed to the model rather than to random error, and for a good fit of a model, $R^{2}$ should be at least $80 \%$ (Cao et al. 2008). The suitability of the model was confirmed by a satisfactory $R^{2}$ value of 0.9576 , which means that $95.76 \%$ of the variability in the response could be explained by the model and that $5 \%$ of the variations occur while performing the experiments, thus indicating a realistic fit of the model to the experimental data (Table 3). The $R^{2}$ coefficient measures the number of reductions in the variability of the response obtained using the independent factors within the model and confirms a satisfactory adjustment of the proposed model to the experimental data. The adjusted determination coefficient $R^{2}$ value was 0.8982 indicating adequate signal, and this high value also supports that the model was highly significant. The coefficient of variation $(\mathrm{CV})$ is the ratio of the standard error of the estimate to the mean value of the observed response, expressed as a percentage, and a model with a CV below $15 \%$ can be considered reasonably reproducible as it suggests higher reliability of the experiment and demonstrates greater reliability of the trials (Cao et al. 2008; Tesfaye et al. 2018b; Limkar et al. 2019). In the current study, the CV of $5.01 \%$ indicates a high degree of precision in the experiment. Adequate precision measures the signal-to-noise ratio, and a ratio greater than four is desirable. For the present BBD, a ratio of 14.501 indicates an adequate signal suggesting that this model can be used to navigate the design space.

The interactive effects between the response variable and the test variables are graphically illustrated as 3D-response surface plots generated by the model, as represented in Fig. 2. The elliptical or circular shape of contours in $3 \mathrm{D}$ plots helps to predict the major interaction between the variables (Tesfaye et al. 2018b). An elliptical contour plot is indicative of highly significant interactions between the variables. From these plots, it is evident that a $\mathrm{pH}$ of 7.1-7.2 and a cultivation time of $\sim 27 \mathrm{~h}$ will result in high cell density $\left(\mathrm{OD}_{600}\right.$ of 2.2$)$. The cell density decreases at higher $\mathrm{pH}$ or decreased cultivation time (Fig. 2a). It is evident that yeast extract of $\sim 8 \mathrm{~g}$ $\mathrm{L}^{-1}$ enhanced biomass production (Fig. $2 \mathrm{~b}$ ). Nitrogen is an absolute requirement for cell growth and is assimilated for the synthesis of amino acids glutamine and glutamate (Cheng et al. 2015). Yeast extract comprises the water-soluble components of the yeast cell and is the main nitrogen source for bacterial growth. It is rich in growth-stimulating compounds such as peptides, carbohydrates, salts, vitamins, and free amino acids. Therefore, it is a useful ingredient in media for the cultivation of microorganisms as it supports protein synthesis and cell growth, and reduces the consumption rate of the carbon source, and minimizes the accumulation of by-products 

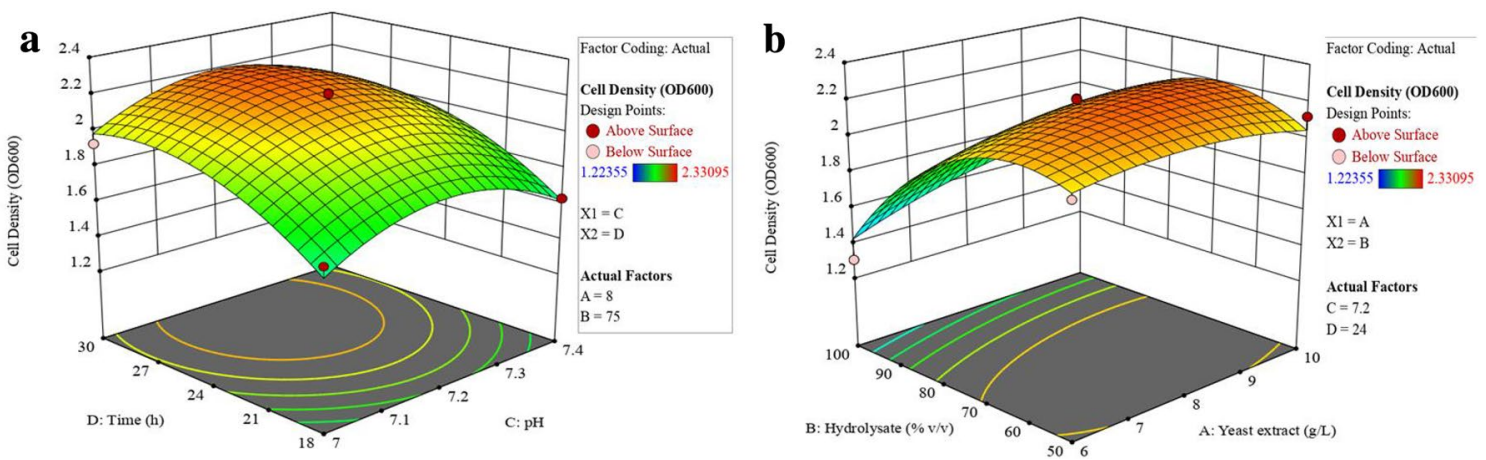

Fig. 2 Three-dimensional (3D) response surface generated by the model for the independent variables that affect the yield of biomass; time and $\mathrm{pH}$ (a) and concentration of hydrolyzate and yeast extract (b)

(Cheng et al. 2015; Nguyen and Tran 2018). Ferreira and Schlottbom (2016) found that as little as $1 \mathrm{~g} \mathrm{~L}^{-1}$ of yeast extract was sufficient to obtain high yields of B. sacchari, whereas Andersen and Jayaraman (2003) obtained the maximum cell density of $B$. thuringiensis subsp. galleriae when $19.7196 \mathrm{~g} \mathrm{~L}^{-1}$ was used in the cultivation medium.

A hydrolyzate concentration of $\sim 65 \%$ allowed for a cell density of $\mathrm{OD}_{600}$ of 2.2 , with concentrations above or below this range being less effective for yielding high cell density biomass (Fig. 2b). During the hydrolysis of cellulosic biomass, sugars are not the only by-product. Toxic cell inhibitors such as volatile organic acids, furfurals, and acid-soluble lignin are also released (Larsson et al. 1999). The inhibitory effect of phenolic and other aromatic compounds on microbial growth and product yield is variable. One possible mechanism is that phenolic compounds such as furfural and 5-hydroxymethylfurfural (5-HMF) interfere with the cell membrane by influencing its functions and changing its protein-tolipid ratio (Peters 2006; Zhang et al. 2018). Two common detoxification procedures to eliminate microbial inhibitors include separation by adsorption of inhibitors using activated carbon and over-liming. Such detoxification methods significantly reduce the concentration of inhibitors, thereby having a positive influence on the growth of biomass. However, detoxification processes are timeconsuming and expensive (Kucera et al. 2017). Yu and Stahl (2008) observed that diluting hydrolyzate to about $50 \% \mathrm{v} / \mathrm{v}$ was better for cell growth and that the dilution effect significantly reduced the toxicity of the hydrolyzate. In the present study, it is possible that when using $100 \%(\mathrm{v} / \mathrm{v})$ hydrolyzate, the presence of toxic compounds negatively affected cell proliferation resulting in lower cell density. In order to achieve a concentration of 50 or $75 \%$ of hydrolyzate, the hydrolyzate was diluted with a basal salt medium. Therefore, it is plausible that the simple dilution of hydrolyzate reduced the concentration of cell inhibiting toxic compounds, thus making the medium more favorable for cell growth. Furthermore, previous enzyme screening assays revealed that $B$. thuringiensis used in the present study synthesizes ligninase (Govender 2013). Ligninases can degrade furfural, HMF, or change their composition or structure to less toxic forms, thereby detoxifying lignocellulosic hydrolyzates (Yang et al. 2018). Values outside this range showed low efficiency for biomass production, confirming that the range of the chosen variables in the experimental design was conducive to obtain high yields of cell biomass.

\section{Model validation}

The model in the present study was validated by conducting experiments under the predicted conditions. Postanalysis of the design was used to determine the point prediction, and a mean cell density at $\mathrm{OD}_{600}$ of 2.28011 was predicted using the factors; $8.77 \mathrm{~g} \mathrm{~L}^{-1}$ yeast extract; $66.63 \%$ hydrolyzate $(\mathrm{v} / \mathrm{v})$; a fermentation $\mathrm{pH}$ of 7.18 ; and an incubation time of $27.22 \mathrm{~h}$. After duplicate experimental trials on two separate occasions, a maximum $\mathrm{OD}_{600}$ of 2.4175 was attained. The difference between experimental and predicted values revealed a good correlation amongst the observed and predicted results, thus verifying the validity of the response model and the reality and accuracy of optimal conditions for the variables.

\section{Batch fermentation and CFBF}

Figure 3a depicts the time course of batch cultivation of $B$. thuringiensis for PHA production, and the kinetic parameters are presented in Table 4. CFBF cycles 2, 3 , and 4 were observed to significantly affect the yield of biomass (CDW) and PHA yield $(p<0.05)$. During batch cultivation, the culture exhibited an initial lag phase of around $4 \mathrm{~h}$, after which it grew exponentially, resulting in a biomass yield of $7.75 \mathrm{~g} \mathrm{~L}^{-1}$ (CDW) and $3.22 \mathrm{~g} \mathrm{~L}^{-1}$ of PHA in $30 \mathrm{~h}$, resulting in a PHA 

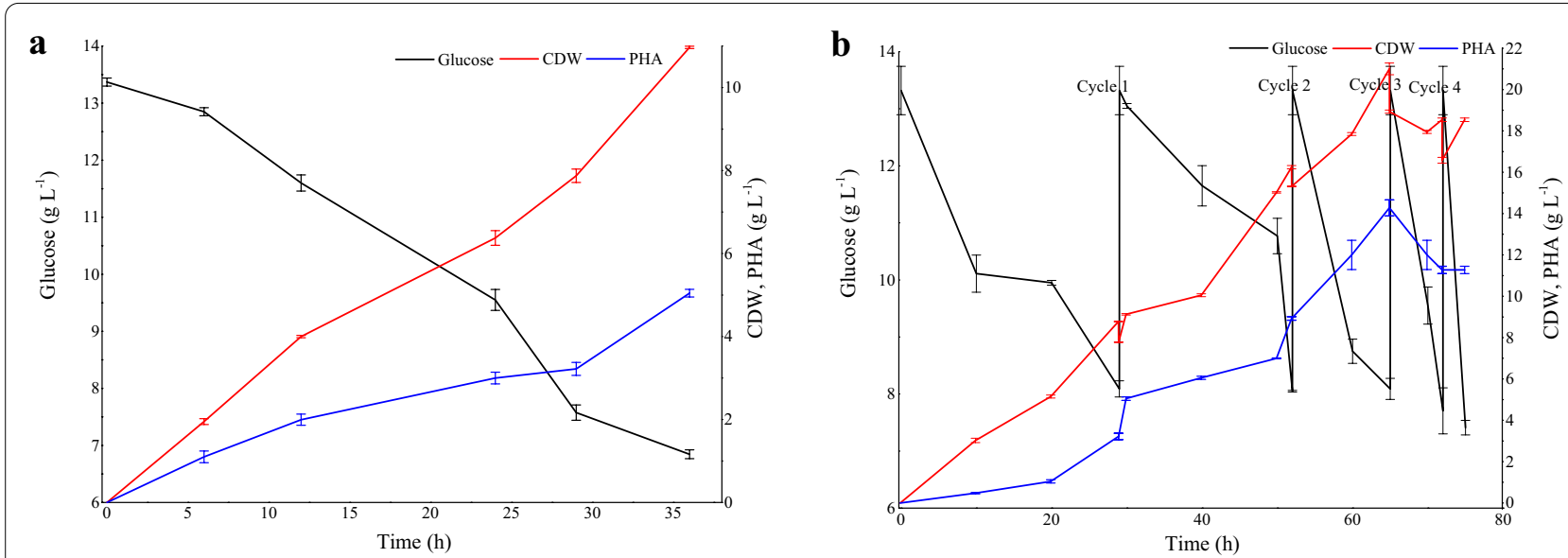

Fig. 3 Kinetics of cell proliferation, carbon consumption and PHA production by B. thuringiensis in batch fermentation (a) and cyclic fed-batch fermentation (b)

productivity of $0.107 \mathrm{~g} \mathrm{~L}^{-1} \mathrm{~h}^{-1}$. The culture reached the stationary phase after $38 \mathrm{~h}$. It was important to establish the batch growth and product kinetics since this established the basic kinetic parameters that were used for the CFBF for enhanced PHA formation. Wang and Liu (2014) found that wood extract hydrolyzate contributed to enhanced PHB production by Burkholderia cepacia in batch fermentation and obtained $16.8 \mathrm{~g} \mathrm{~L}^{-1}$ of PHB after 9 days. A $72 \mathrm{~h}$ batch fermentation of Cupriavidus necator using waste office paper hydrolyzate resulted in cell biomass, PHB production, and PHB content of $7.74 \mathrm{~g} \mathrm{~L}^{-1}, 4.45 \mathrm{~g} \mathrm{~L}^{-1}$, and $57.52 \%$, respectively (Annamalai et al. 2017). The CFBF cultivation of B. thuringiensis is depicted in Fig. 3b, and the kinetic parameters are presented in Table 4 . The conversion of the batch fermentation to CFBF started at $29 \mathrm{~h}$ when the glucose concentration was $8.09 \mathrm{~g} \mathrm{~L}^{-1}$, resulting in the first cycle of removal and subsequent re-filling of an equal volume of fresh medium. The slight decrease in cell concentration observed during the cycles is due to the addition of fresh medium that diluted the remaining fermentation medium; however, it gradually increased with continuous cell proliferation. The second cycle occurred at $52 \mathrm{~h}$, and the third cycle at $65 \mathrm{~h}$. It was observed that the culture continuously maintained its metabolic activities and continued to produce PHA even after three cycles. Based on the observation of continuously high cell density and PHA yields and glucose consumption, a fourth cycle was initiated at $72 \mathrm{~h}$. This however, was not successful, and the yields decreased in comparison with CFBF cycles $1-3$. Therefore, three cycles were sufficient to successfully achieve high cell density and PHA yields using the CFBF strategy. At the end of the third CFBF cycle (after $65 \mathrm{~h}$ ), cell biomass of $20.99 \mathrm{~g} \mathrm{~L}^{-1}$ was noted with a PHA concentration of $14.28 \mathrm{~g} \mathrm{~L}^{-1}$ resulting in a yield of $68.03 \%$. This cyclic strategy yielded an overall PHA productivity of $0.219 \mathrm{~g} \mathrm{~L}^{-1} \mathrm{~h}^{-1}$. The CFBF resulted in an almost threefold increase in biomass concentration and fourfold increase in PHA concentration, respectively, as compared with batch cultivation (Table 4). During batch cultivations, nutrients such as carbon and nitrogen substrates become limited during the course of fermentation, particularly during the exponential growth phase, thus affecting the growth of the culture. Furthermore, initiating batch fermentation with very high concentrations of substrates in the cultivation medium stands a risk of substrate inhibition phenomenon. Therefore, CFBF could be a better option as it ensures a controlled feeding of the substrate and adequate nutrient availability during the entire cultivation, thereby curbing the potential problem of substrate inhibition. CFBF also eliminates time-consuming activities such as cleaning, filling, and sterilizing a bioreactor to initiate batch cultivation (Gahlawat and Srivastava 2018). To the best of our knowledge, to date, there are no reports on CFBF cultivation for biomass and PHA production by B. thuringiensis. Gahlawat and Srivastava (2018) used CFBF to increase PHB concentration and productivity by Azohydromonas australica. They observed that at the end of the $60 \mathrm{~h}$ fermentation, the biomass and PHB yield was $24.90 \mathrm{~g} \mathrm{~L}^{-1}$ and $18.79 \mathrm{~g} \mathrm{~L}^{-1}$, respectively, with a PHA productivity of $0.29 \mathrm{~g} \mathrm{~L}^{-1} \mathrm{~h}^{-1}$. Ibrahim and Steinbüchel (2010) also investigated the use of CFBF to achieve high biomass growth and PHB productivity by the thermophilic bacterium, Chelatococcus sp. MW10 in a $42 \mathrm{~L}$ bioreactor. After three cycles and $265 \mathrm{~h}$ fermentation, a cell density of $115 \mathrm{~g} \mathrm{~L}^{-1}$, PHB concentration of $13.6 \mathrm{~g} \mathrm{~L}^{-1} \mathrm{~h}^{-1}$, and PHB yield of $11.8 \%$ was noted. The CFBF strategy employed by Haas et al. 
Table 4 Growth and product kinetic parameters of $B$. thuringiensis during the batch and cyclic fed-batch fermentation

\begin{tabular}{|c|c|c|c|c|c|c|c|}
\hline Fermentation & Time (h) & $\begin{array}{l}\text { Residual } \\
\text { glucose }\left(\mathrm{g} \mathrm{L}^{-1}\right)\end{array}$ & $\operatorname{CDW}\left(\mathrm{g} \mathrm{L}^{-1}\right)$ & $\mathrm{PHA}\left(\mathrm{g} \mathrm{L}^{-1}\right)$ & PHA yield (\%) & $\begin{array}{l}\text { Biomass } \\
\text { productivity (g } \\
\mathrm{L}^{-1} \mathrm{~h}^{-1} \text { ) }\end{array}$ & $\begin{array}{l}\text { PHA } \\
\text { productivity (g } \\
\mathrm{L}^{-1} \mathrm{~h}^{-1} \text { ) }\end{array}$ \\
\hline Batch & 36 & 6.98 & 7.75 & 3.22 & 41.54 & 0.258 & 0.107 \\
\hline CFBF cycle 1 & 29 & 8.09 & 8.75 & 3.22 & 36.8 & 0.302 & 0.111 \\
\hline CFBF cycle 2 & 52 & 8.05 & 16.29 & 8.95 & 54.94 & 0.313 & 0.172 \\
\hline CFBF cycle 3 & 65 & 7.94 & 20.99 & 14.28 & 68.03 & 0.323 & 0.219 \\
\hline CFBF cycle 4 & 72 & 7.96 & 18.52 & 11.28 & 60.90 & 0.257 & 0.157 \\
\hline
\end{tabular}

(2017) found that Cupriavidus necator achieved a high PHB concentration of $3.1 \mathrm{~g} \mathrm{~L}^{-1}$ and reached a cell density of $148 \mathrm{~g} \mathrm{~L}^{-1}$, which yielded $76 \%$ PHB.

\section{FTIR characterization of PHAs}

FTIR was used to confirm PHA production by identifying the presence of functional groups present in PHA (Fig. 4). The peaks present at the ester, methylene, and terminal hydroxyl group are typically representative of the polymeric structure of PHAs (Apparao and Krishnaswamy 2015). The exact peak location and intensity are known to vary with the polymer chain length, concentration, and crystallinity of the PHA. The distinguishing peak of PHA is located around $1700-1738 \mathrm{~cm}^{-1}(\mathrm{C}=\mathrm{O}$ stretch) and a series of intense peaks located at 1000$1400 \mathrm{~cm}^{-1}$ (C-O stretch), which correspond to the ester group present in the molecular chain of highly ordered crystalline structures (Getachew and Woldesenbet 2016). The prominent pinnacle present at $\sim 1708 \mathrm{~cm}^{-1}$ corresponds to ester carbonyl $(\mathrm{C}=\mathrm{O})$ extending the vibration of PHB (Fig. 4). Observation of adsorption bands around 1380, 1450, 2930, 1650, and $3400 \mathrm{~cm}^{-1}$ corresponds to $-\mathrm{CH}_{3},-\mathrm{CH}_{2}, \mathrm{CH}, \mathrm{C}-\mathrm{O}$, and $\mathrm{O}-\mathrm{H}$ groups, respectively, which is typically present in pure PHB (Labuzek and Radecka 2001). The strong peaks at $2923-2975 \mathrm{~cm}^{-1}$ are due to the $\mathrm{C}-\mathrm{H}$ stretching methyl and methylene groups of alkanes, which are usually demonstrated by PHA polymers. The broad peak at $3396 \mathrm{~cm}^{-1}$ indicates the presence of $\mathrm{O}-\mathrm{H}$ stretching of alcohol (terminal $\mathrm{OH}$ group) (Fig. 4) (Sindhu et al. 2016). The presence of copolymer like PHBV is denoted by a characteristic absorption peak in the region of 2933-2972 $\mathrm{cm}^{-1}$. Overall, the FTIR spectra of the extracted PHAs are comparable with

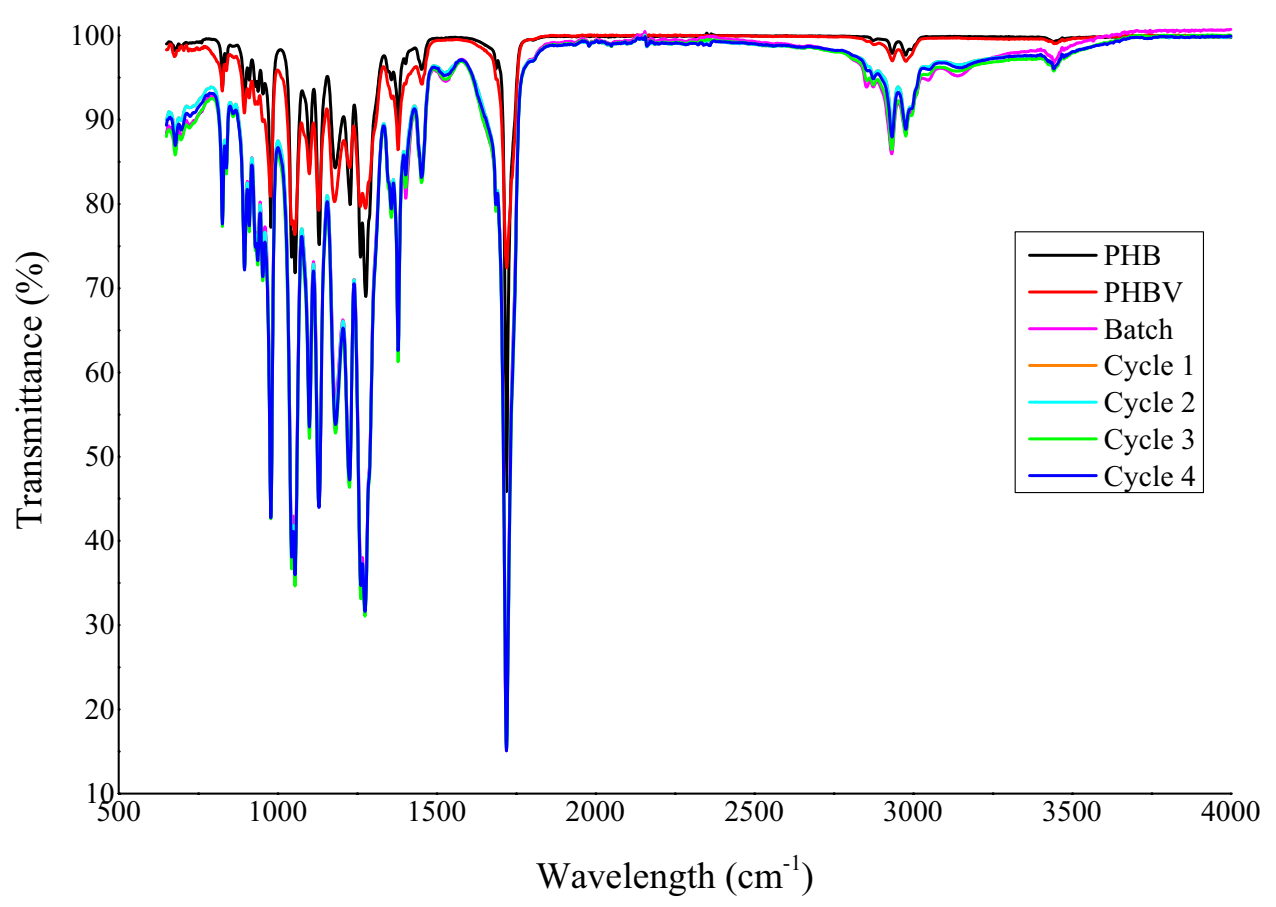

Fig. 4 FTIR spectra of commercial PHB and PHBV compared with the PHAs extracted from B. thuringiensis after each cycle of the CFBF 
commercial PHB and PHBV as they display prominent peaks at the wavelengths unique to PHA.

\section{Polymer composition}

To identify the composition of the produced PHAs, Py/GC-MS and THM-GC were employed as these techniques permit accurate detection, characterization, and semi-quantification of PHA-monomeric moieties incorporated by the isolate (Torri et al. 2014; Baidurah et al. 2015). The variations in the polymer composition of PHAs extracted after batch and CFBF are highly significant $(p<0.01)$. Statistical analysis revealed that CFBF cycles 2,3 , and 4 significantly affected the mol\% of $\mathrm{HB}$ and $\mathrm{HV}$ in the polymer $(p<0.05)$, whereas only CFBF cycles 3 and 4 significantly affected the mol\% of $\mathrm{HHx}$ in the polymers $(p<0.05)$. It was surprising to observe that the commercial PHB used in the present study is not a PHB homopolymer as it contained $10.19 \%$ HV (Table 5). In the present study, it was observed that after the first cyclic event, a copolymer containing $62.61 \% \mathrm{HB}$ and $37.39 \% \mathrm{HV}$ was elucidated, whereas after CFBF cycles 2-4, the HB-HV-HHx terpolymer was noted (Table 5 and Additional file 1: Figures S1-S7). This differs from previous reports, which state that PHB was the predominant biopolymer synthesized when agrowaste-derived hydrolyzates from bagasse ( $\mathrm{Yu}$ and Stahl 2008), wheat bran (Annamalai and Sivakumar 2016), rice straw (Sindhu et al. 2016), wood (Wang and Liu 2014), wheat straw (Ferreira and Schlottbom 2016), and waste office paper (Annamalai et al. 2017) were the sole carbon source in the fermentation.

\section{Thermal properties}

TGA analysis

The thermal degradation profiles for commercial PHB and PHBV and the PHAs extracted from B. thuringiensis after each cyclic event are shown in Fig. 5. The initial $\left(T_{5 \%}\right)$ and maximum $\left(T_{\max }\right)$ degradation temperatures for each sample are presented in Table 5 and Fig. 5. All of the samples displayed a similar thermal decomposition pattern, and the thermal degradation for all the samples occurs in a one-stage decomposition trend under a nitrogen atmosphere (Fig. 5a). The TGA curve shows that the weight loss (\%) of all the samples occurs in two stages. In comparison with commercial PHB and PHBV, there is a noticeable difference in the initial and maximum thermal degradation. The initial degradation occurred in the range of $255.54-269.66{ }^{\circ} \mathrm{C}$ with a weight loss of $\sim 1-8 \%$ of the total mass noted (Table 5; Fig. 5a). This weight loss results from the evaporation of physically adsorbed impurities or solvents like methanol, chloroform, etc., used during the extraction and separation processes (Pradhan et al. 2018). The maximum thermal degradation of the samples occurred around $286.77{ }^{\circ} \mathrm{C}$ to $292.21{ }^{\circ} \mathrm{C}$, beyond the melting point of PHB (Table 5; Fig. 5b). The main mechanism of thermal decomposition of PHB corresponds to $\beta$-elimination of $\mathrm{PHB}$ chains that facilitate the formation of crotonic acid, dimeric, trimeric, and tetrameric volatiles (Vahabi et al. 2019). A shift in maximum degradation temperature of the PHAs is observed whereby $T_{\max }$ increased after each cyclic event compared with commercial PHB and PHBV (Table 5; Fig. 5b). Thus, it can be concluded that these PHAs have a slightly higher thermal stability compared with commercial PHB. The higher thermal stability of the extracted polymer could also be attributed to a more crystalline morphology (Pradhan et al. 2018). It is important to acknowledge high decomposition temperatures as it is a crucial factor for polymer processing in the industry since the material has to be tolerant and resist structural degradation, considering the high temperatures used for extrusion and injection molding to manufacture biodegradable films

Table 5 Polymer composition, thermal properties, and thermal degradation of PHA extracted from B. thuringiensis after each cycle of the cyclic fed-batch fermentation compared with commercial PHB, and PHBV

\begin{tabular}{|c|c|c|c|c|c|c|c|c|c|c|c|c|}
\hline & \multicolumn{3}{|c|}{$\begin{array}{l}\text { Polymer composition } \\
\text { (mol \%) }\end{array}$} & \multicolumn{2}{|c|}{$\begin{array}{l}\text { Degradation } \\
\text { temperature }\left({ }^{\circ} \mathrm{C}\right)\end{array}$} & \multicolumn{7}{|c|}{ Thermal properties } \\
\hline & $\mathrm{HB}$ & HV & $\mathrm{HHx}$ & $T_{5 \%}$ & $T_{\max }$ & $T_{\mathrm{g}}\left({ }^{\circ} \mathrm{C}\right)$ & $T_{\mathrm{m} 1}\left({ }^{\circ} \mathrm{C}\right)$ & $T_{\mathrm{m} 2}\left({ }^{\circ} \mathrm{C}\right)$ & $\Delta H_{\mathrm{m}}\left(\mathrm{J} \mathrm{g}^{-1}\right)$ & $T_{\mathrm{c}}\left({ }^{\circ} \mathrm{C}\right)$ & $\Delta H_{\mathrm{c}}\left(\mathrm{J} \mathrm{g}^{-1}\right)$ & $X_{c}(\%)$ \\
\hline Batch fermentation & 82.13 & 17.87 & - & 217.15 & 286.81 & 4.98 & 155.4 & 166.64 & 85.59 & 78.07 & 62.61 & 59 \\
\hline CFBF cycle 1 & 77.45 & 22.55 & - & 222.52 & 286.87 & 4.95 & 149.89 & 160.77 & 83.93 & 83.69 & 65.89 & 57 \\
\hline CFBF cycle 2 & 54.56 & 42.80 & 2.64 & 248.60 & 289.96 & 4.71 & 147.17 & 158.35 & 59.76 & 115.18 & 54.96 & 40 \\
\hline CFBF cycle 3 & 52.48 & 43.78 & 3.74 & 253 & 290.66 & 4.65 & 143.77 & 154.53 & 55.77 & 118.54 & 53.50 & 38 \\
\hline CFBF cycle 4 & 48.43 & 46.39 & 5.18 & 275.54 & 292.21 & 4.60 & 129.53 & 140.82 & 49.77 & 122.14 & 46.53 & 34 \\
\hline Commercial PHB & 89.81 & 10.19 & - & 269.66 & 286.77 & 5.02 & 171.65 & 174.69 & 90.35 & 75.5 & 63.92 & 62 \\
\hline Commercial PHBV & 43.35 & 56.65 & - & 264.04 & 288.32 & 4.85 & 138.22 & 146.94 & 60.55 & 113.17 & 58.06 & 41 \\
\hline
\end{tabular}



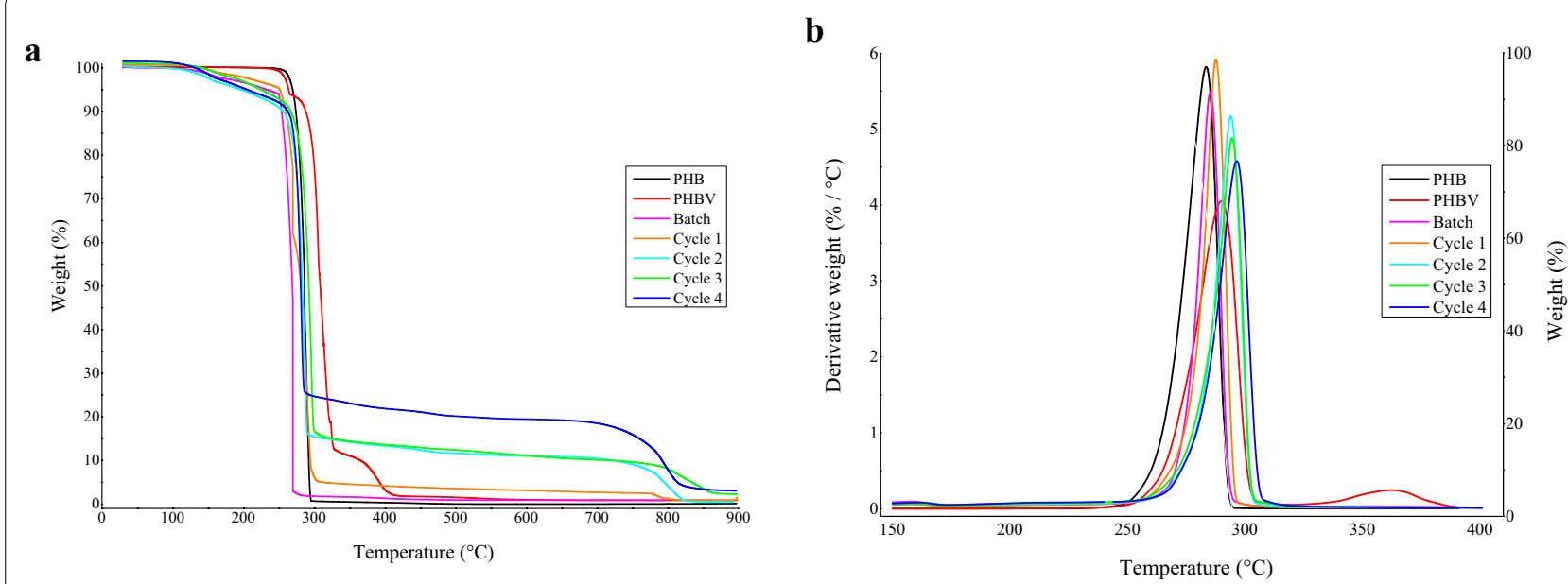

Fig. 5 TGA (a) and DTG (b) thermograms of commercial PHB and PHBV, and the PHAs obtained after each cycle of the cyclic fed-batch fermentation

and molded pieces (Pradhan et al. 2018). Hassan et al. (2016) reported that the maximum thermal degradation for PHA obtained from Bacillus sp. 34 occurred between 237 and $320^{\circ} \mathrm{C}$, a range that was also observed in the present study. A similar observation was made for polymers obtained from Alcaligenes sp., where the maximum thermal degradation was between 220 and $315^{\circ} \mathrm{C}$ (Melo et al. 2012). Pillai et al. (2017) found the thermal degradation of the PHB synthesized by $B$. aryabhattai to have an initial polymer degradation temperature at $247{ }^{\circ} \mathrm{C}$ and maximum degradation at $287^{\circ} \mathrm{C}$, which is similar to the degradation temperatures of the terpolymer PHA retrieved after the second cyclic event (Table 5). However, their standard PHB showed the initial and maximum degradations at $212{ }^{\circ} \mathrm{C}$ and $266^{\circ} \mathrm{C}$, respectively, which is substantially lower compared with the commercial PHB used in the present study (Table 5). The cyclic events resulted in PHAs having a noticeable shift in maximum thermal degradation temperature ranging from 250.77 to $262.56{ }^{\circ} \mathrm{C}$, which is higher than the commercial PHB and PHBV, respectively. However, Sandhya et al. (2013) concluded that their sample contained many different hydroxyalkanoate monomers since they observed lower degradation temperatures compared to that of the standard PHB.

\section{DSC analysis}

Differential scanning calorimetry analysis was conducted to elucidate the thermal transitions that a polymer undergoes as the sample is heated. The thermal transitions are manifested in terms of glass transition temperature $\left(T_{\mathrm{g}}\right)$, melting point $\left(T_{\mathrm{m}}\right)$, melting enthalpy $\left(\Delta H_{\mathrm{m}}\right)$, crystallization temperature $\left(T_{\mathrm{c}}\right)$, crystallization enthalpy $\left(\Delta H_{\mathrm{c}}\right)$, and degree of crystallinity $\left(X_{\mathrm{c}}\right)$ are summarized in Table 5 . The DSC cooling and second heating cycle curves of commercial PHB and PHBV, as well as the PHAs, extracted from $B$. thuringiensis after each cyclic event, are shown in Fig. 6. The variations observed for $T_{\mathrm{g}}, T_{\mathrm{m}} T_{\mathrm{c}}$, and $X_{\mathrm{c}}$ of PHAs extracted after batch fermentation and each cyclic event of CFBF are highly significant $(p<0.01)$. The $T_{\mathrm{g}}$ varied from 4.60 to $5.02{ }^{\circ} \mathrm{C}$ (Table 5 ). The structure of the polymer results in the initial movement of the polymer chain at a relatively lower temperature resulting in a decreased value of glass transition temperature (Pradhan et al. 2018). There was a wide variation in the $T_{\mathrm{c}}$ ranging from 75.5 to $118.54{ }^{\circ} \mathrm{C}$ (Table 5; Fig. 6a). Crystallization occurs due to the gain of mobilization of the polymer chains, which allows the polymer chains to organize and form crystals. The increasing $T_{\mathrm{c}}$ relates to the crystalline region in the polymer where the molecular chains are closely packed, and the secondary links are stronger in contrast to amorphous regions of a polymer. Therefore, high temperatures are required for the deformation of the polymer chain (Beber et al. 2018). PHAs with low $T_{\mathrm{c}}$ are problematic for melt-processing polymer procedures (Volova et al. 2013). The $T_{\mathrm{c}}$ for PHB synthesized from $B$. megaterium was $\sim 113{ }^{\circ} \mathrm{C}$, which is comparable to commercial PHBV analyzed in the present study (Chaijamrus and Udpuay 2008). The narrower crystallization peaks for PHBV and PHA from CFBF cycles 2, 3, and 4 observed in Fig. 6 a are owed to the higher content of $\mathrm{HV}$ in the respective polymers and are also indicative of crystals with a more homogeneous size distribution. The larger crystallization peaks as observed for commercial PHB, PHA from batch fermentation and CFBF cycle 1 (Fig. 6a) are less desirable as they represent the formation of crystals with lower perfection and larger size distribution (Montanheiroa et al. 2016). In Fig. 6b, two distinct $T_{\mathrm{m}}$ endothermic peaks are observed for each 

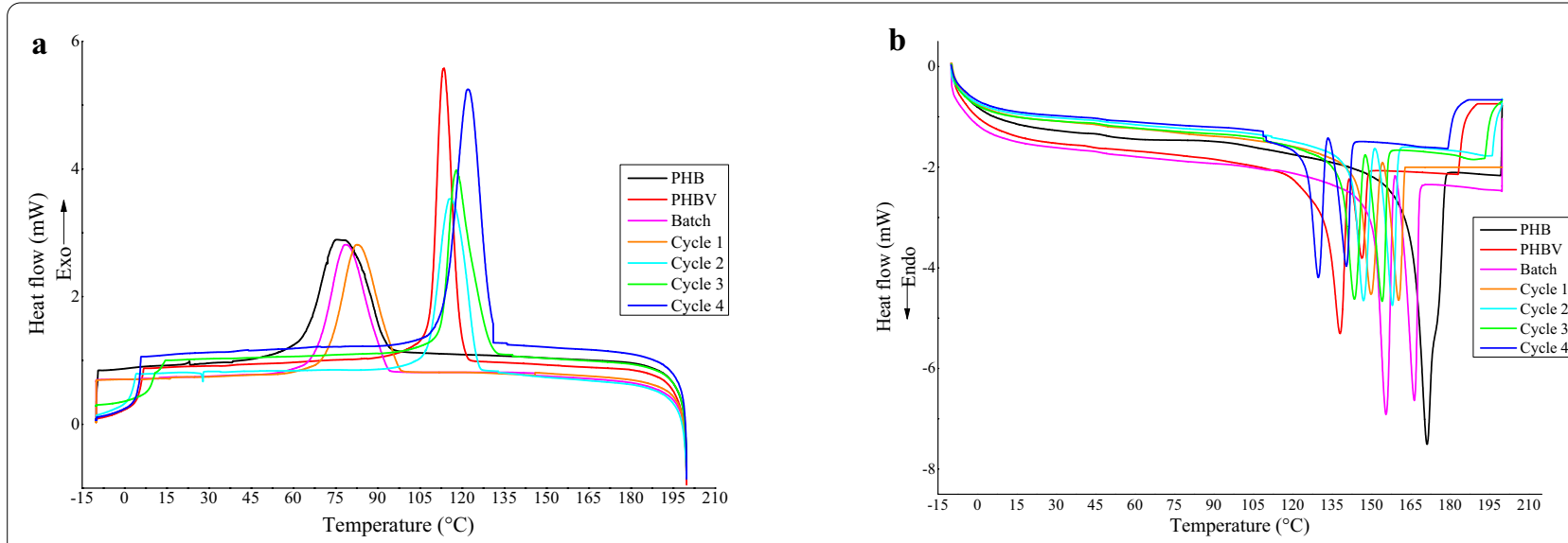

Fig. 6 DSC thermogram displaying the cooling cycle (a) and the second heating cycle (b) used to characterize commercial PHB and PHBV, and the PHA extracted from B. thuringiensis after each cycle of the cyclic fed-batch fermentation

sample, which is presented as a minor peak, followed by a dominant major peak at a higher temperature. For commercial PHB, the second peak appears as a shoulder peak of the main peak. The first $T_{\mathrm{m}}$ ranged from 129.53 to $171.65{ }^{\circ} \mathrm{C}$, whereas the second $T_{\mathrm{m}}$ ranged from 140.82 to $174.69{ }^{\circ} \mathrm{C}$ (Table 5). The first melting peak originates from the melting of crystals formed during PHA sample preparation, and the second peak is due to the fusion of crystals formed during the heating phase of the DSC (Buzarovska and Grozdanov 2009). Other major contributors to the double melting behavior that results in multiple melting peaks include two different crystalline domains; the melting-re-crystallization-remelting mechanism; melting of different types of crystals with different sizes; different modifications; and thermal stabilities; or the melting of crystals with different lamellar thickness. Small and less perfect crystals melt at a lower temperature, and the larger and more perfect ones melt at a higher temperature (Wellen et al. 2015; Montanheiroa et al. 2016; Vahabi et al. 2019). Multiple melting peaks are a common feature of semi-crystalline polymers (Wellen et al. 2015). Multi-component PHAs, as observed in the present study, which have other alkanoate components or long side chains, tend to have a lower $T_{\mathrm{m}}$ (Saranya and Shenbagarathai 2011; Sandhya et al. 2013). Sharma et al. (2017) reported that the copolymer PHBV produced by Pseudomonas putida had a $T_{\mathrm{m}}$ of 137$170{ }^{\circ} \mathrm{C}$, which is higher than the $T_{\mathrm{m}}$ of PHBV observed in the present study. The low $T_{\mathrm{m}}$ of the PHA characterized at CFBF cycle 4 is not unusual. Surendran et al. (2020) explain that incorporation of a minor quantity (5 mol\%) of $\mathrm{HHx}$ can reduce the melting point to below $155^{\circ} \mathrm{C}$. The decreasing $T_{\mathrm{m}}$ in the present study is consistent with previous reports that had shown a decrease in melting temperature when the non-HB monomer fraction of the copolymer increased (Kehail et al. 2015). A low $T_{\mathrm{m}}$ is indicative of a polymer containing a high $\mathrm{HV}$ fraction (Surendran et al. 2020). A low $T_{\mathrm{m}}$ is also desirable as it implies that the polymer can be processed at a low temperature, making the polymer suitable for soft products such as films with improved ductility and flexibility (Liu et al. 2019). The presence of a pronounced gap between $T_{\mathrm{m}}$ and $T_{\max }$ observed in the present study (Table 5) is an important favorable characteristic of a polymer. It is indicative of polymers with a wide melt-processing window, thereby increasing the range of products (films, fibers, hollow forms, etc.,) that can potentially be produced from the polymer, as well as increasing the range of processing methods the polymer can withstand (solution spinning, extrusion, injection molding, etc.,) (Volova et al. 2013). The degree of crystallinity $\left(X_{c}\right)$ is one of the most important characteristics among the different mechanical performance and processability properties of the polymer and is summarized in Table 5. To minimize polymer processing challenges, $X_{\mathrm{c}}$ should ideally be $\leq 50 \%$; otherwise, corrective actions are required resulting in challenges during polymer processing that can increase the operation price (Rodrigues et al. 2019). It was observed that the $X_{\mathrm{c}}$ for the cyclic events decreased from $52 \%$ at CFBF 1 to $34 \%$ after CFBF 4 (Table 5). Thus, the synthesized PHAs are less crystalline compared with commercial PHB and PHBV. Chaijamrus and Udpuay (2008) reported $X_{c}=60 \%$ for PHA extracted from $B$. megaterium, resulting in a highly crystalline polymer. That $X_{\mathrm{c}}$ is substantially higher compared with the $X_{\mathrm{c}}$ observed for PHAs in the present study. The $X_{\mathrm{c}}$ of the PHAs extracted from $B$. thuringiensis are lower than that of the commercial PHB and PHBV (Table 5). The decreasing $X_{\mathrm{c}}$ observed for PHAs from CFBF cycles 2, 3, and 4 is attributed to the presence of $\mathrm{HHx}$ specifically, as the 
incorporation of $\mathrm{HHx}$ in the polymer chain reduces the crystallinity of the PHA (Surendran et al. 2020). The $X_{\mathrm{c}}$ for PHBV obtained after batch fermentation, and CFBF cycle 1 is $59 \%$ and $57 \%$, respectively, which is a relatively high crystalline PHBV copolymer. In addition, the $X_{\mathrm{c}}$ for the PHBV copolymers observed in the present study is similar to the $X_{\mathrm{c}}$ of commercial PHB (62\%) than the $X_{\mathrm{c}}$ of commercial PHBV (41\%) (Table 5). This observation is explained by Shang et al. (2012), whereby a high HV content in the polymer, as observed in commercial PHBV, decreases the crystallinity of a polymer. Surendran et al. (2020) further explain the isodimorphism behavior phenomenon that occurs exclusively in PHBV copolymers. When the HV fraction of the copolymer is $<37 \%$, the HV lattice can co-crystallize into the same lattice as HB. The properties of the resultant polymer are similar to $\mathrm{PHB}$, such as high crystallinity. A polymer with high crystallinity is stiff and brittle in nature (Singh et al. 2015; Możejko-Ciesielska and Kiewisz 2016). Therefore, a PHA with low crystallinity, such as the terpolymer obtained after CFBF cycles 2, 3, and 4, is advantageous as it is less brittle, thus increasing the range of applications of the polymer (Chaijamrus and Udpuay 2008). Furthermore, incorporating $\mathrm{HV}$ and $\mathrm{HHx}$ monomers into PHAs as well as having a combination of a low $T_{\mathrm{g}}$ and a low $X_{\mathrm{c}}$, as observed for PHAs in the present study, are favorable (Table 5). These characteristics change the mechanical performance of the polymer as it imparts elastomeric behavior rendering flexible polymers suitable for medical applications (Rai et al. 2011). In the present study, TGA and DSC analysis aided in highlighting the critical role that incorporation of non-HB units into the polymer chain plays for the enhancement of physical properties of PHA polymers.

\section{Conclusions}

This study assessed the ability and efficiency of B. thuringiensis to assimilate glucose-rich hydrolyzate produced by enzymatic saccharification of PPMS. The isolate was able to use this hydrolyzate as sole carbon source for cell proliferation and PHA production. The statistical optimization using BBD aided in determining an optimal cultivation medium to produce high cell density biomass and also determined the success of the CFBF strategy. The CFBF strategy proved successful for simultaneously achieving high cell density and enhancing PHA production by $B$. thuringiensis. Three cycles of culture broth removal and subsequent re-filling with fresh medium at $29 \mathrm{~h}, 52 \mathrm{~h}$ and $65 \mathrm{~h}$ resulted in a maximum PHA yield of $14.28 \mathrm{~g} \mathrm{~L}^{-1}$ with the overall productivity of $0.219 \mathrm{~g} \mathrm{~L}^{-1} \mathrm{~h}^{-1}$. The present work demonstrated a threefold increase in PHA yield and a fourfold increase in productivity compared with batch cultivation. The isolate was a good producer of co- and ter-polymers. However, the polymer composition, and thermal properties varied after each cyclic event. On the basis of proof of concept, this study exhibits encouraging results. A range of very cheap raw materials are available for industrial PHA production, and coupled with the practicality of this strategy, it has potential to be scaled-up to pilot level for technoeconomic feasibility analysis.

\section{Supplementary Information}

The online version contains supplementary material available at https://doi. org/10.1186/s40643-021-00361-x.

Additional file 1: Figure S1. Pyrogram of commercial PHB. Figure S2. Pyrogram of commercial PHBV. Figure S3. Pyrogram of PHA extracted after cycle 1 of cyclic fed-batch fermentation. Figure S4. Pyrogram of PHA extracted after cycle 2 of cyclic fed-batch fermentation. Figure S5. Pyrogram of PHA extracted after cycle 3 of cyclic fed-batch fermentation. Figure S6. Pyrogram of PHA extracted after cycle 4 of cyclic fed-batch fermentation.

\section{Abbreviations}

PHA: Polyhydroxyalkanoate; PHB: Polyhydroxybutyrate; PHBV: Polyhydroxybutyrate-valerate copolymer; CFBF: Cyclic fed-batch fermentation; HHx: Polyhydroxyhexanoate; rpm: Revolutions per minute; BBD: Box-Behnken design; 3D: 3-Dimensional; CDW: Cell dry weight; HPLC: High-performance liquid chromatography; TAPPI: Technical Association of the Pulp and Paper Industry; FTIR: Fourier transform infrared; THM-GC: Thermally assisted hydrolysis and methylation-gas chromatography; Py/GC-MS: Pyrolysis/gas chromatography-mass spectroscopy; TMAH: Tetramethylammonium hydroxide; TGA: Thermogravimetric analysis; DSC: Differential scanning calorimetry; $T_{\mathrm{g}}$ : Glass transition temperature; $T_{m}$ : Melting temperature; $\Delta H_{m}$ : Melting enthalpy; $T_{c}$ : Crystallization temperature; $\Delta H_{c}$ : Crystallization enthalpy; $X_{c}$ : Degree of crystallinity; $\mathrm{OD}_{600}$ : Optical density at $600 \mathrm{~nm}$.

\section{Acknowledgements}

None.

\section{Authors' contributions}

SS: conceptualization, conducted all of the experimental work, analyzed and interpreted all of the data, writing - original draft, reviewing and editing. RG: conceptualization of CFBF for PHA production, writing - reviewing and editing, supervision. PL, BS, KP: writing —-reviewing and editing, supervision. All authors read and approved the final manuscript.

\section{Funding}

The authors thank the Department of Science and Technology (DST) Waste Roadmap project (South Africa) and the Council for Scientific and Industrial Research for funding the study.

\section{Availability of data and materials}

All data generated or analyzed during this study are included in the manuscript.

Ethics approval and consent to participate Not applicable.

Consent for publication

Not applicable.

Competing interests

The authors declare that they have no competing interests. 


\begin{abstract}
Author details
1 Discipline of Microbiology, University of KwaZulu-Natal (Westville Campus), Durban, South Africa. ${ }^{2}$ Biorefinery Industry Development Facility, Chemicals Cluster, Council for Scientific and Industrial Research, Durban, South Africa. ${ }^{3}$ Discipline of Chemical Engineering, University of KwaZulu-Natal, Durban, South Africa. ${ }^{4}$ Department of Biotechnology and Food Technology, Durban University of Technology, Durban, South Africa.
\end{abstract}

Received: 3 September 2020 Accepted: 5 January 2021

Published online: 30 January 2021

\section{References}

Andersen RKI, Jayaraman K (2003) Influence of carbon and nitrogen sources on the growth and sporulation of Bacillus thuringiensis var galleriae for biopesticide production. Chem Biochem Eng Q 17:225-231

Annamalai N, Sivakumar N (2016) Production of polyhydroxybutyrate from wheat bran hydrolysate using Ralstonia eutropha through microbial fermentation. J Biotechnol 237:13-17. https://doi.org/10.1016/j.jbiot ec.2016.09.001

Annamalai N, Al-battashi H, Al-bahry S, Sivakumar N (2017) Biorefinery produc tion of poly-3-hydroxybutyrate using waste office paper hydrolysate as feedstock for microbial fermentation. J Biotechnol 265:25-30. https://doi. org/10.1016/j.jbiotec.2017.11.002

Apparao U, Krishnaswamy VG (2015) Production of polyhydroxyalkanoate (PHA) by a moderately halotolerant bacterium Klebsiella pneumoniae U1 isolated from rubber plantation area. Int J Environ Bioremediat Biodegrad 3:54-61. https://doi.org/10.12691/ijebb-3-2-3

Aramvash A, Moazzeni Zavareh F, Gholami Banadkuki N (2018) Comparison of different solvents for extraction of polyhydroxybutyrate from Cupriavidus necator. Eng Life Sci 18:20-28. https://doi.org/10.1002/elsc.201700102

Argyropoulos D, Lynch HC (1997) Recombinant $\beta$-glucanase production and plasmid stability of Bacillus subtilis in cyclic fed batch culture. Biotechnol Tech 11:187-190. https://doi.org/10.1023/A:1018409715438

Baidurah S, Kubo Y, Kuno M et al (2015) Rapid and direct compositional analysis of poly(3-hydroxybutyrate-co-3-hydroxyvalerate) in whole bacterial cells by thermally assisted hydrolysis and methylation-gas chromatography. Anal Sci 31:79-83. https://doi.org/10.2116/analsci.31.79

Beber VC, de Barros S, Banea MD et al (2018) Effect of Babassu natural filler on PBAT/PHB biodegradable blends: an investigation of thermal, mechanical, and morphological behavior. Materials 11:1-16. https://doi.org/10.3390/ ma11050820

Buzarovska A, Grozdanov A (2009) Crystallization kinetics of poly(hydroxybutyrate-co-hydroxyvalerate) and poly(dicyclohexylitaconate) PHBV/PDCHI blends: thermal properties and hydrolytic degradation. J Mater Sci 44:1844-1850. https://doi. org/10.1007/s10853-008-3236-3

Cao Y, Meng DJ, Lu J, Long J (2008) Statistical optimization of xylanase production by Aspergillus niger AN-13 under submerged fermentation using response surface methodology. African J Biotechnol 7:631-638. https:// doi.org/10.5897/AJB07.921

Chaijamrus S, Udpuay N (2008) Production and characterization of polyhydroxybutyrate from molasses and corn steep liquor produced by Bacillus megaterium ATCC 6748. Agric Eng Int CIGR Ejournal 1-12

Cheng L, Wang J, Fu Q et al (2015) Optimization of carbon and nitrogen sources and substrate feeding strategy to increase the cell density of Streptococcus suis. Biotechnol Biotechnol Equip 29:779-785. https://doi. org/10.1080/13102818.2015.1039465

Czyrski A, Sznura J (2019) The application of Box-Behnken-design in the optimization of HPLC separation of fluoroquinolones. Sci Rep 9:1-10. https:// doi.org/10.1038/s41598-019-55761-z

Duff SJB, Moritz JW, Andersen KL (1994) Simultaneous hydrolysis and fermentation of pulp mill primary clarifier sludge. Can J Chem Eng 72:10131020. https://doi.org/10.1002/cjce.5450720611

Ferreira BS, Schlottbom C (2016) Production of polyhydroxybutyrate from lignocellulosic hydrolysates-optimization of Bacillus sacchari fermentation and scale up from $2 \mathrm{~L}$ to $200 \mathrm{~L}$. Eppendorf 1-6

Gahlawat G, Srivastava AK (2018) Enhancing the production of polyhydroxyalkanoate biopolymer by Azohydromonas australica using a simple empty and fill bioreactor cultivation strategy. Chem Biochem Eng Q 31:479-485. https://doi.org/10.15255/CABEQ.2017.1148

García YG, Carlos CJCM et al (2015) Procurement of fermentable sugars from cardboard waste for the cultivation of yeasts for biotechnological use. Rev Mex Ciencias For 6:88-105

Getachew A, Woldesenbet F (2016) Production of biodegradable plastic by polyhydroxybutyrate (PHB) accumulating bacteria using low cost agricultural waste material. BMC Res Notes 9:1-9. https://doi.org/10.1186/ s13104-016-2321-y

Gholamveisi N, Azar SM, Moravej R (2018) Bacillus thuringiensis strain NG, a novel isolated strain for production of various polyhydroxyalkanoates. Biol J Microorg 6:13-20

Govender L (2013) Seasonal variation of microflora and their effects on the quality of wood chips intended for pulping. PhD Dissertation, University of KwaZulu-Natal

Gowda V, Shivakumar S (2014) Agrowaste-based polyhydroxyalkanoate ( $\mathrm{PHA})$ production using hydrolytic potential of Bacillus thuringiensis IAM 12077. Braz Arch Biol Technol 57:55-61. https://doi.org/10.1590/ S1516-89132014000100009

Haas C, El-najjar T, Virgolini N et al (2017) High cell-density production of poly(3-hydroxybutyrate) in a membrane bioreactor. N Biotechnol 37:117-122. https://doi.org/10.1016/j.nbt.2016.06.1461

Hanrahan G, Garza C, Garcia E, Miller K (2007) Experimental design and response surface modeling: A method development application for the determination of reduced inorganic species in environmental samples. J Environ Inform 9:71-79. https://doi.org/10.3808/jei.200700088

Hassan MA, Bakhiet EK, Ali SG, Hussien HR (2016) Production and characterization of polyhydroxybutyrate (PHB) produced by Bacillus sp. isolated from Egypt. J Appl Pharm Sci 6:46-51. https://doi.org/10.7324/ JAPS.2016.60406

Ibrahim MHA, Steinbüchel A (2010) High-cell-density cyclic fed-batch fermentation of a poly(3-hydroxybutyrate)-accumulating thermophile, Chelatococcus sp. strain MW10. Appl Environ Microbiol 76:7890-7895. https://doi.org/10.1128/AEM.01488-10

Kehail AA, Foshey M, Chalivendra V, Brigham CJ (2015) Thermal and mechanical characterization of solvent-cast poly(3-hydroxybutyrateco-3-hydroxyhexanoate). J Polym Res 22:1-8. https://doi.org/10.1007/ s10965-015-0872-6

Kucera D, Benesova P, Ladicky P et al (2017) Production of polyhydroxyalkanoates using hydrolyzates of spruce sawdust: comparison of hydrolyzates detoxification by application of overliming, active carbon, and lignite. Bioengineering 4:1-9. https://doi.org/10.3390/bioenginee ring 4020053

Kunasundari B, Sudesh K (2011) Isolation and recovery of microbial polyhydroxyalkanoates. Express Polym Lett 5:620-634. https://doi. org/10.3144/expresspolymlett.2011.60

Łabuzek S, Radecka I (2001) Biosynthesis of PHB tercopolymer by Bacillus cereus UW85. J Appl Microbiol 90:353-357. https://doi.org/10.104 6/j.1365-2672.2001.01253.x

Larsson S, Palmqvist E, Hahn-Hägerdal B et al (1999) The generation of fermentation inhibitors during dilute acid hydrolysis of softwood. Enzyme Microb Technol 24:151-159. https://doi.org/10.1016/S0141 -0229(98)00101-X

Limkar MB, Pawar SV, Rathod VK (2019) Statistical optimization of xylanase and alkaline protease co-production by Bacillus spp using BoxBehnken Design under submerged fermentation using wheat bran as a substrate. Biocatal Agric Biotechnol 17:455-464. https://doi. org/10.1016/j.bcab.2018.12.008

Liu J, Zhao Y, Diao M et al (2019) Poly(3-hydroxybutyrate-co-3-hydroxyvalerate) production by Rhodospirillum rubrum using a two-step culture strategy. J Chem 2019:1-8. https://doi.org/10.1155/2019/8369179

Lynch HC, Bushell ME (1995) The physiology of erythromycin biosynthesis in cyclic fed batch culture. Microbiology 141:3105-3111. https://doi. org/10.1099/13500872-141-12-3105

Madrid LM, Díaz JCQ (2011) Ethanol production from paper sludge using Kluyveromyces marxianus. Dyna 78:185-191

Marques S, Alves L, Roseiro JC, Gírio FM (2008) Conversion of recycled paper sludge to ethanol by SHF and SSF using Pichia stipitis. Biomass Bioenergy 32:400-406. https://doi.org/10.1016/j.biombioe.2007.10.011

Martínez-Sanz M, Villano M, Oliveira C et al (2014) Characterization of polyhydroxyalkanoates synthesized from microbial mixed cultures and 
of their nanobiocomposites with bacterial cellulose nanowhiskers. N Biotechnol 31:364-376. https://doi.org/10.1016/j.nbt.2013.06.003

Martin-Sampedro R, Eugenio ME, Revilla E et al (2011) Integration of kraft pulping on a forest biorefinery by the addition of a steam explosion pretreatment. BioResources 6:513-528. https://doi.org/10.15376/biore S.6.1.513-528

Melo JDD, Carvalho LFM, Medeiros AM et al (2012) A biodegradable composite material based on polyhydroxybutyrate (PHB) and carnauba fibers. Compos Part B Eng 43:2827-2835. https://doi.org/10.1016/j. compositesb.2012.04.046

Montanheiroa TLdA, Passadora FR, de Oliveiraa MP et al (2016) Preparation and characterization of maleic anhydride grafted poly(hydroxybutirateco-hydroxyvalerate)_PHBV-g-MA. Mater Res 19:229-235

Moritz JW, Duff SJB (1996) Simultaneous saccharification and extractive fermentation of cellulosic substrates. Biotechnol Bioeng 49:504-511. https://doi.org/10.1002/(SICI)1097-0290(19960305)49:5\%3c504 $\because$ :AID-BIT3\%3e3.0.CO;2-N

Możejko-Ciesielska J, Kiewisz R (2016) Bacterial polyhydroxyalkanoates: stil fabulous? Microbiol Res 192:271-282. https://doi.org/10.1016/j.micre s.2016.07.010

Muhammadi S, Afzal M, Hameed S (2015) Bacterial polyhydroxyalkanoateseco-friendly next generation plastic: production, biocompatibility, biodegradation, physical properties and applications. Green Chem Lett Rev 8:56-77. https://doi.org/10.1080/17518253.2015.1109715

Munir S, lqbal S, Jamil N (2015) Polyhydroxyalkanoates (PHA) production using paper mill wastewater as carbon source in comparison with glucose. J Pure Appl Microbiol 9:453-460

Nguyen H-YT, Tran G-B (2018) Optimization of fermentation conditions and media for production of glucose isomerase from Bacillus megaterium using response surface methodology. Scientifica 2018:1-11. https:// doi.org/10.1155/2018/6842843

Peters D (2006) Carbohydrates for fermentation. Biotechnol J 1:806-814. https://doi.org/10.1002/biot.200600041

Pillai AB, Kumar AJ, Thulasi K, Kumarapillai H (2017) Evaluation of shortchain-length polyhydroxyalkanoate accumulation in Bacillus aryabhattai. Braz J Microbiol 48:451-460. https://doi.org/10.1016/j. bjm.2017.01.005

Pirt SJ (1974) The theory of fed batch culture with reference to the penicillin fermentation. J Appl Chem Biotechnol 24:415-424. https://doi. org/10.1002/jctb.5020240706

Pradhan S, Dikshit PK, Moholkar VS (2018) Production, ultrasonic extraction, and characterization of poly(3-hydroxybutyrate) (PHB) using Bacillus megaterium and Cupriavidus necator. Polym Adv Technol 29:2392-2400. https://doi.org/10.1002/pat.4351

Prasetyo J, Kato T, Park EY (2010) Efficient cellulase-catalyzed saccharification of untreated paper sludge targeting for biorefinery. Biomass Bioenergy 34:1906-1913. https://doi.org/10.1016/j.biombioe.2010.07.02

Rai R, Keshavarz T, Roether JA et al (2011) Medium chain length polyhydroxyalkanoates, promising new biomedical materials for the future. Mater Sci Eng R Rep 72:29-47. https://doi.org/10.1016/j. mser.2010.11.002

Rodrigues PR, Nunes JMN, Lordelo LN, Druzian JI (2019) Assessment of polyhydroxyalkanoate synthesis in submerged cultivation of Cupriavidus necator and Burkholderia cepacia strains using soybean as substrate. Braz J Chem Eng 36:73-83. https://doi.org/10.1590/0104-6632.20190 $361 s 20170267$

Rohini D, Phadnis S, Rawal SK (2006) Synthesis and characterization of poly$\beta$-hydroxybutyrate from Bacillus thuringiensis R1. Indian J Biotechno 5:276-283

Sandhya M, Aravind J, Kanmani P (2013) Production of polyhydroxyalkanoates from Ralstonia eutropha using paddy straw as cheap substrate. Int J Environ Sci Technol 10:47-54. https://doi.org/10.1007/ s13762-012-0070-6

Saranya V, Shenbagarathai R (2011) Production and characterization of PHA from recombinant E. coli harbouring PHACl gene of indigenous Pseudomonas sp. LDC-5 using molasses. Braz J Microbiol 42:1109-1118. https://doi.org/10.1590/S1517-838220110003000032

Schroeder BG, Zanoni PRS, Magalhães WLE et al (2015) Evaluation of biotechnological processes to obtain ethanol from recycled paper sludge. J Mater Cycles Waste Manage 19:463-472. https://doi.org/10.1007/ s10163-015-0445-0
Shang L, Fei Q, Zhang YH et al (2012) Thermal properties and biodegradability studies of poly(3-hydroxybutyrate-co-3-hydroxyvalerate). J Polym Environ 20:23-28. https://doi.org/10.1007/s10924-011-0362-9

Sharma PK, Munir RI, de Kievit T, Levin DB (2017) Synthesis of polyhydroxyalkanoates (PHAs) from vegetable oils and free fatty acids by wild-type and mutant strains of Pseudomonas chlororaphis. Can J Microbiol 63:1009-1024. https://doi.org/10.1139/cjm-2017-0412

Sheu D, Wang Y, Lee C (2000) Rapid detection of polyhydroxyalkanoateaccumulating bacteria isolated from the environment by colony PCR. Microbiology 146:2019-2025. https://doi.org/10.1099/00221 287-146-8-2019

Sin MC, Tan IKP, Annuar MSM, Gan SN (2014) Viscoelastic, spectroscopic, and microscopic characterization of novel bio-based plasticized poly(vinyl chloride) compound. Int J Polym Sci. https://doi. org/10.1155/2014/846189

Sindhu R, Kuttiraja M, Prabisha TP et al (2016) Development of a combined pretreatment and hydrolysis strategy of rice straw for the production of bioethanol and biopolymer. Bioresour Technol 215:110-116. https:// doi.org/10.1016/j.biortech.2016.02.080

Singh M, Kumar P, Ray S, Kalia VC (2015) Challenges and opportunities for customizing polyhydroxyalkanoates. Indian J Microbiol 55:235-249. https://doi.org/10.1007/s12088-015-0528-6

Singh S, Sithole B, Lekha P et al (2021) Pretreatment and enzymatic saccharification of sludge from a prehydrolysis kraft and kraft pulping mill. J Wood Chem Technol. https://doi.org/10.1080/02773813.2020.18568 80

Smitha KV, Pradeep BV (2017) Application of Box-Behnken design for the optimization of culture conditions for novel fibrinolytic enzyme production by Bacillus altitudinis S-CSR 0020. J Pure Appl Microbiol 11:1447-1456. https://doi.org/10.22207/JPAM.11.3.28

Surendran A, Lakshmanan M, Chee JY et al (2020) Can polyhydroxyalkanoates be produced efficiently from waste plant and animal oils? Front Bioeng Biotechnol 8:1-15. https://doi.org/10.3389/fbioe .2020 .00169

Tesfaye T, Sithole B, Ramjugernath D, Ndlela L (2018a) Optimisation of surfactant decontamination and pre-treatment of waste chicken feathers by using response surface methodology. Waste Manage 72:371-388. https://doi.org/10.1016/j.wasman.2017.11.013

Tesfaye T, Sithole B, Ramjugernath D, Ndlela L (2018b) Valorisation of waste chicken feathers: optimisation of decontamination and pre-treatment with bleaching agents using response surface methodology. Waste Manag 72:371-388. https://doi.org/10.1016/j.scp.2018.02.003

Thammasittirong A, Saechow S, Thammasittirong SN-R (2017) Efficient polyhydroxybutyrate production from Bacillus thuringiensis using sugarcane juice substrate. Turk J Biol 41:992-1002. https://doi.org/10.3906/ biy-1704-13

Torri C, Cordiani H, Samorì C et al (2014) Fast procedure for the analysis of poly(hydroxyalkanoates) in bacterial cells by off-line pyrolysis/ gas-chromatography with flame ionization detector. J Chromatogr A 1359:230-236. https://doi.org/10.1016/j.chroma.2014.07.008

Vahabi H, Michely L, Moradkhani G et al (2019) Thermal stability and flammability behavior of poly(3-hydroxybutyrate) (PHB) based composites. Materials (Basel) 12:1-14. https://doi.org/10.3390/ma12142239

Volova TG, Zhila NO, Shishatskaya El et al (2013) The physicochemical properties of polyhydroxyalkanoates with different chemical structures. Polym Sci Ser A 55:427-437. https://doi.org/10.1134/S0965545X130700 80

Wang Y, Liu S (2014) Production of (R)-3-hydroxybutyric acid by Burkholderia cepacia from wood extract hydrolysates. AMB Express 4:1-10. https:// doi.org/10.1186/s13568-014-0028-9

Wellen RMR, Rabello MS, Júnior ICA et al (2015) Melting and crystallization of poly(3-hydroxybutyrate): effect of heating/cooling rates on phase transformation. Polímeros 25:296-304. https://doi. org/10.1590/0104-1428.1961

Yang S, Franden MA, Yang Q et al (2018) Identification of inhibitors in lignocellulosic slurries and determination of their effect on hydrocarbonproducing microorganisms. Front Bioeng Biotechnol 6:1-14. https:// doi.org/10.3389/fbioe.2018.00023

Yu J, Stahl H (2008) Microbial utilization and biopolyester synthesis of bagasse hydrolysates. Bioresour Technol 99:8042-8048. https://doi. org/10.1016/j.biortech.2008.03.071 
Zhang W, Alvarez-Gaitan JP, Dastyar W et al (2018) Value-added products derived from waste activated sludge: A biorefinery perspective. Water 10:1-20. https://doi.org/10.3390/w10050545

\section{Publisher's Note}

Springer Nature remains neutral with regard to jurisdictional claims in published maps and institutional affiliations.
Submit your manuscript to a SpringerOpen ${ }^{\odot}$ journal and benefit from:

- Convenient online submission

- Rigorous peer review

- Open access: articles freely available online

- High visibility within the field

- Retaining the copyright to your article

Submit your next manuscript at $\boldsymbol{\nabla}$ springeropen.com 